University of Louisville

ThinkIR: The University of Louisville's Institutional Repository

Electronic Theses and Dissertations

$1-1930$

\title{
The platonic lover of Elizabethan poetry.
}

Dorcas Douglass Ray

University of Louisville

Follow this and additional works at: https://ir.library.louisville.edu/etd

Part of the English Language and Literature Commons

\section{Recommended Citation}

Ray, Dorcas Douglass, "The platonic lover of Elizabethan poetry." (1930). Electronic Theses and Dissertations. Paper 1190.

https://doi.org/10.18297/etd/1190

This Master's Thesis is brought to you for free and open access by ThinkIR: The University of Louisville's Institutional Repository. It has been accepted for inclusion in Electronic Theses and Dissertations by an authorized administrator of ThinkIR: The University of Louisville's Institutional Repository. This title appears here courtesy of the author, who has retained all other copyrights. For more information, please contact thinkir@louisville.edu. 


\section{UNIVERS ITY OF LOUISVILLE}

THE PLATONIC LOVER OF ELIZABETHAN POETRY

A Dissertation

Submitted to the Faculty

of the Graduate School of the University of Louisville

In Partial Fulfillment of the

Requirements for the Degree

of Master of Arts

Department of Engl1sh

By

Dorcas Douglass Ray

1930 
THE PLATONIC LOVER OF ELIZABETHAN POETRY 


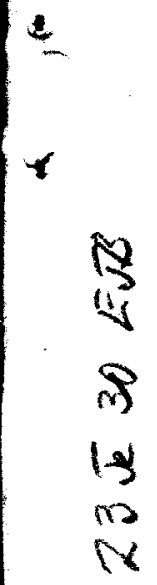

MY MOTHER 
TABLE OF CONTENTS 


\section{CONTENTS}

Chapter

Page

I. The Original Meaning of Platonic Love. 1

II. Renalssance Platonism.............. 9

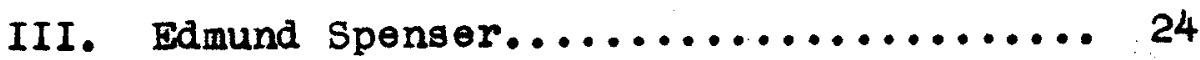

IV. N11l1am shakespeare............... 42

v. Other Platonic Ellzabethans......... 65

vI. Conclusion.................... 87 
OHAPTER I

THE ORIGINAL MEANING OF PLATONIC LOVE 
CHAPTER I

THE ORIGINAL MEANING OF PLATONIC. LOVE

Just what is the meaning of Platonic love? It Is a term that has caught the attention of scholars, poets, and plain men, in many countries and during many centuries. Perhaps its wide appeal accounts for the varled and tortuous shapes its meaning has assumed as it has passed through the inquisitive and often callous fingers of the multitudes. It is a term applied popularly today to a kind of abstract, passionless frlendship, which, to the practicalminded Amerlcan, can exist only in theory. Few who use the term Platonic love or Platonic friendship have paused first to read the pages of the symposium, where 1tg signiflcance is carefully explained to socrates by the remarkable Mantinean woman, Diotima. One would expect to find Plato, of all persons, a Platonic lover, and is for the moment startled by Walter Pater's assertion that "Plato himself had not been always a mere Platonic lover; was rather, naturally, as he makes Socrates say of himself, subject to the influence of fair persons" and knew "all the ways of lovers in the literal sense." 1

I

Pater, Walter. Plato and Platonism. p. 121 
A Platonic lover is the product of many stages of growth; and so, Plato, though always potentially a Platonic lover, did not know the fuliness of spirItual love unt 11 he had experienced the varying emotions which led naturally up to 1t. The first impulge of the Platonic lover is a consciousness within himself of incompletion. Fithout this self-dissatisfaction there can be no mental or spiritual progress, for "the man who does not feel himgelf defective has no desire for that whereof he feels no defect." 1 There must be a human longing for something not within himself, a "continual aspiration and advance towards a goal never attained." ${ }^{2}$ It is "all that desire of good things and of being happy." since this reaching out after the good awakens in man the hope of ultimately finding permanent satisfaction, it necessarily follows that "love is of immortal1ty." 4 The fact that love is constantly in want of that which it does not possess leads Plato to conceive of it as being the offspring of Poverty. First then of the essential characteristics of the

Plato. With an Eng. Translation by W.R.M. Lamb. vol. 5 , p. 183 .

Grote, George. Plato. vol. 3, p. 10. 3 Plato. vol. 5, p. 187 4 Ibid. p. 193 
Platonic lover is that he be restless, dissatlofled, unhappy with things as they are.

Next, he must assay to remedy the matter, for love is not alone the child of hapless Poverty but of zealous Resource. The lover at once begins his task of achleving happiness. If he seeks it along the avenues of wealth or fame or musle or philosophy, he at once ceases to be the Platonic lover, who can find satisfaction in but one way and that is by means of both the body and the soul. It is birth in beauty that distingulshes the Platonic lover from all others. Where then is he to look for this beauty which is so essential to the gratification of his desire? It is everywhere about him, for he is living In a world of beautiful living substances, since "for some reason the eternal 1dea of beauty has left visible coples of 1tself, shadors, antitypes." ${ }^{3}$ These beautiful forms recall distant memorles; they arouse strong emotions and impulses toward generation and self-perpetuation. "Hence springs the love of beauty - or rather of procreation in the beautiful - whereby satisfaction is obtained for this

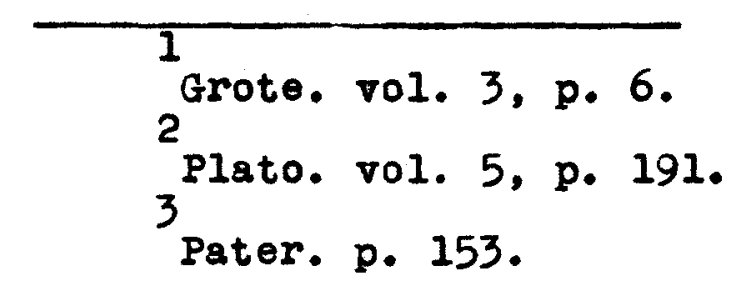


restless and impatient agitation." " The first instinctive effort to obtain happiness and thereby immortality is to beget children whose new bodies w111 I1ve to perpetuate the aging bodieg of their parents. Here we do not find a Plato so abstract in his principles that he w111 not countenance the normal relationshlp between man and woman, for says Diotima, "Such is the right approach and Induction to love matters." 2 But mark! She said "the right approsch", for the Platonic lover must go on. "Beginning from obvious beauties he must for the sake of that highest beauty be ever climbing aloft." ${ }^{3}$ The Greek philosopher considers the beauty of a youth more inspirational than that of a maid, for he desires a beauty of mind and soul, which, in his oplnion, woman, for all her physical charm, does not possess. The devotion to a beautiful and accomplished youth fires the lover with an incentive to recognize and promote in him all manifestations of mental beauty which are In harmony with the physical, so as to ralse him to the greatest attainable perfection of human nature.

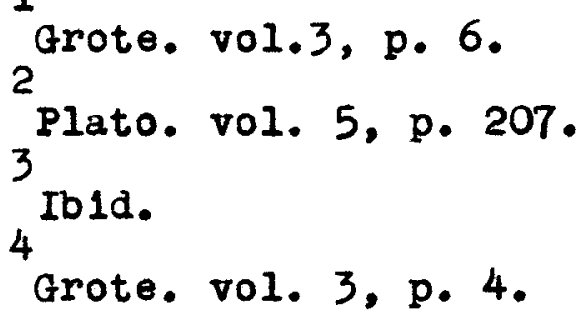


In such endeavors the mind of the lover, concentrated upon a noble purpose, brings forth virtuous thoughts which provide his questing soul with a more complete satisfaction than the pleasing presence of a son. The Platonlc lovers, then, In the real sense, are those "persons who in their souls still more than in their bodies concelve and bring forth prudence and virtue in general, and of these the begetters are all the poets and those craftsmen who are styled inventors." 1 They are those who, consclous first of a great mental and spiritual poverty, have the determination and resourcefulness to secure sustenance through replenishing themselves in beauty. "It is a divine affair, this engendering and bringing to birth, an immortal olement in the creature that is mortal." ${ }^{2}$ The Platonic lover has now reached the stage in h1s development when he no longer need look to some youth to point him to the cltadels of beauty. He neod no longer depend upon the eye, which in 1 ts circumscribed area can detect only "obvious beauties". For he "1s become a lover of the inviaible, but still a lover, and therefore, 11terally, a seer of 1t, carrying an elaborate cultivation of the bodily senses,

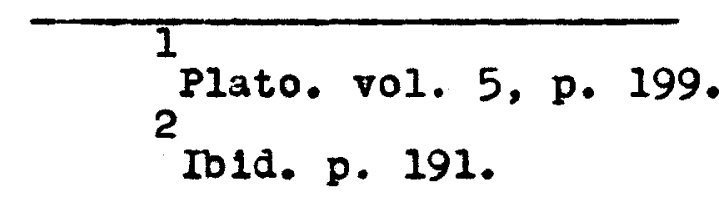


of eje and ear -- Into the world of intellectual abstractions." ${ }^{1}$ Pater emphasizes the fact that the Platonic lover does not coldly contemplate abstractions, but he loves them with the same intensity with which he once adored a noble youth or a mistress. "Abstract Ideas themselves become anlmated, living persons, almost corporeal, as 15 wh hands and ejes." ${ }^{2}$ at this point in the lover's development one must be careful not to confuse love or Eros, begotten of Poverty and Resouroe, w1th the object loved or Idea, "which 1s absolute, independent of $\frac{t i m e}{3}$ place, clroumstance, and all varlable elements." Love, no matter how far the lover may ascend in his spiritual ecstasies, is still a hungry desire, tearing at his being; the greater his vision of beauty, the more insatiable his longing for an increased revelation. Grote thus marks the apex of the lover's struggle and resourcefulness: "If any man's vision be once sharpened so that he can see beauty pure and absolute, he will have no eyes for the individual manffestations of $1 \mathrm{t}$ In fine gold, fine raiment, brilliant colours, or beautiful youths. Herein we have the climax" of Platonic love.

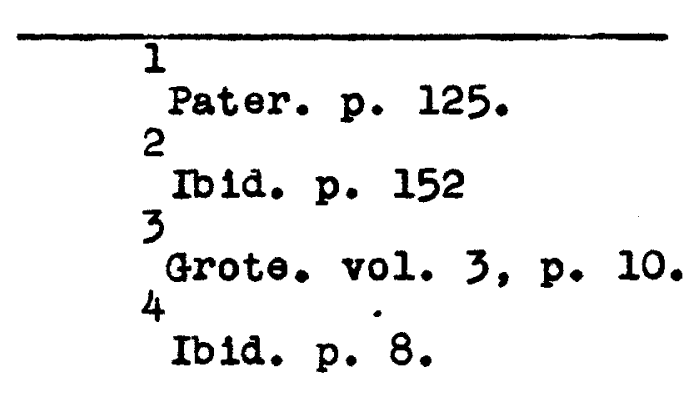


Does the reward of such a lover justify his painful straining after a remote and inaccessible ideal? Let us turn to Dlotima for our answer: "Do you call it a pitiful ilfe for a man to lead - looking that way, observing that vision by the proper means, and having it ever before him? -- In the end he comes to know the very essence of beauty. In that state of IIfe above all others -- a man finds it truly worth while to Ilve as he contemplates essential beauty.-So when he has begotten a true virtue and has reared it up, he is destined to win the friendship of Heaven; he above all men 18 immortal."

May we not then define Platonic love as a starvIng, straining, and finalig a triumphing desire to know God?

Iflato. vol. 5, pp. 207-209. 
CHAPTER II

RENAISSANCE PLATONISM 
CHAPTER II

\section{RENA ISSANCE PLATONISM}

Plato's theory of love passed through many generations of thought before it touched the versatile genlus of the Ellzabethan lyrists. After its inception in the academy of Plato at Athens, it passed first through the Neo-Platonic schools of Syria, Constantinople, and Alexandria, which were making a last attempt to save pagan philosophy from dissolution. Plotinus was the pirst to give a written exposition of the Neo-Platonic philosophy, which "1s an elaborate attempt to bring the transcendent spirItual element of religion into harmony with the philosophy of Plato:"

Greek thought had little influence upon the western world so long as Constantinople remained the headquarters of classical learning. In 1453 the Turks captured Constantinople and many of her scholars fled to Italy, taking with them their treasures of Greok manuscripts. The revived interest in classloal literature that subsequently permeated western Europe gave new Impetus to the vast intellectual 
awakening which had begun in Italy about the middle of the fourteenth century. Philosophical controversy was rife. A Platonic academy was formed at Florence by Cosmo de' Medic1, and bitter opposition arose between the followers of Plato and of Arlstotle. Among the Italian humanists who champloned the Platonic csuse were Lorenzo Valla, Marcilio Ficino, and Glovanni Pico della Mirandola.

Inglishmen, traveling in Italy during the Renaissance perlod, did not return home untouched by the spirit of philosophlcal reasoning and debate centered in the Academy of Florence. Europe was steeped in Platonism, and the Elizabethans' introduction to Plato was through the medium of Italian interpreters, whose Neo-Platonle doctrines set forth the teachings of Plotinus rather than of Plato. Therefore the socalled Platonic tendencies of many sixteenth century English lyrists have a declded Neo-Platonic cast.

With the advent of Christian philosophy, pagan teachings were doomed. Neo-Platonists attempted a compromise which proved futile, and those elements of pagan ph1losophy which were applicable to Chrlstian doctrine ultimately became absorbed by the new religion. Renalssance Platonlsm, whlch so pervaded Ellzabethan England, assayed a mlddle ground between 
pagan and Christian attitudes. Many Platonic enthusiasts, so-called, were more interested in squeezing Plato through the portals of their religlous edifices than they were in striving to understand the original signiflcance of his pagan phllosophy. "By a brave if odd synthesis, the humanists of the Renalssance sought to reconcile through Plotinus and other Neo-Platonists, as well as some of the more sympathetic church Fathors, the flower of Greek thought with the doctrines of Christianity. The three ultimate Neo-Platonic principles -- Good, Intellect, and Soul, were identifled with the three persons of the Trinity." The fact that the two philosophles could be so harmonized accounted for the general popularity of Plato. "The Infusion of Platonism into the thought of Christian men could do no harm, for there was no possibility of competition and no possible place for paganism." Renalsaance Platonlsm, however, became the vehlcle, not only of religlous ecstasy but also of sensual gratiflcation. On the one hand the clay of Platonic beauty was molded into the image of God, while on the other hand it was molded Into the 1mage of the world, for "the Florentines, much as they might spec-

Cory, H. E. Edmund spenser. pp. $346,347$. 2

Renwick, W. L. Edmund Spenser. p. 165. 
ulate upon the supremacy of abstract beauty, the beauty visible only to the mind's eje, actually responded how much more sincerely, passionately to concrete beauty, beauty visible to the eje of sense, -- The Italian of the Rensissance was an exceedingly concrete person. He meant by Beauty, for all Plato, sensuous beauty, the beauty he could touch, see, hear, sinell, taste." 1 Such Platonlsm became synonymous with sensual1gm, with materialism. Fletcher thus quotes Ruskin, who deplored such a gross distortion of Platonic 1deal1sm: "All the Rensissance principles of art tended to the setting Beauty above Truth and seeking for it almajs at the expense of Truth." ${ }^{2}$ Th1s morshlp of beautiful substanoes rather than of beaut1ful 1deas set at naught the teachings of Plato. Harrison points to the essential discrepancy between the Platonic and Neo-Platonic conceptions of beauty. "The great reakness of the theory (of Renaissance Platonism) lay in the fact that it had no moral signifloance, and just here lay the great atrength of Plato's ethics. Although preaching that beauty was a spiritual thing, this phase of Platonic aesthetics never blended with the conception of the beauty of

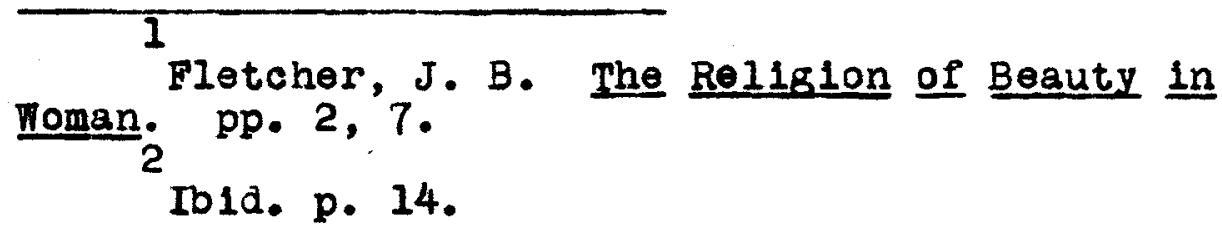


moral goodness. And it falled to do this because It is a theory not of Plato but of Plotinus, who throughout the perlod of the Renaissance was understood to expound the true meaning of Plato's thought!" It 1s true that Plato believed that a lover first needed the stimulus of personal beauty to actuate him to pursue abstrsct beauty. But he sent hem to a beautiful youth for his inspiration. Now "the Renalssance religion of beauty started wrong." It started with the worship of a beautiful woman, and was loathe to leave such charming company for a realm of somewhat chilly ideas. Far different from the obscure Athenian ma1d or matron was the accomplished Itallan lady of the Renalsance. "Tales of precoclous malds becoming, while still in their teens, accomplished orators, poets, scholars in Lat in, even in Greok, go the rounds of Italy", for "In the Renalssance the priestess of Platonic love was the fine lady." ${ }^{3}$ She was to be worshipped from a discreet distance in accordance with Plotinus, who "without exactly condemning marriage, yet commends as the higher love that which rests in passion-

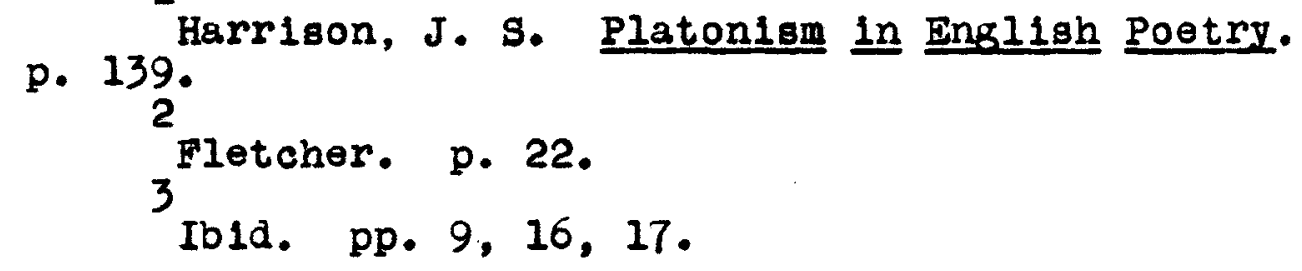


less contemplation of womanly beauty. " 1 The only relat lonship existing between the lover and his lady should be of a spiritual nature. "Under Renalssance Neo-Platonlsm the only duty of woman is to be beaut1ful, to awaken desire, and then to disappear, leaving the desire to be nursed into an ecstasy in which she has no place." 2

Th1s new conception of Platonic love 1s set forth by Cardinal Bembo in Castiglione's Fourth Book of the Courtier. Plato's doctrines are seen anew in the light of Plotinus, of Flcino, of Dante and his circle. "These side influences tended to make paramount the element of Platonism which finds chief utterance In the Symposium: that love is the supreme force, cosmle, moral, religlous; that there are tro loves, heavenly and earthly, the one a desire of the beauty of the sense, the other a desire of the beauty above sense; and that, as sensuous beauty 1s the shadow of supersensuous or spiritual beauty, therefore by following the shadow we may ultimately attain to the reality behind the shadow, and in an ecstasy possess divine beauty 1tself."

Bembo holds physical loveliness to be an un-

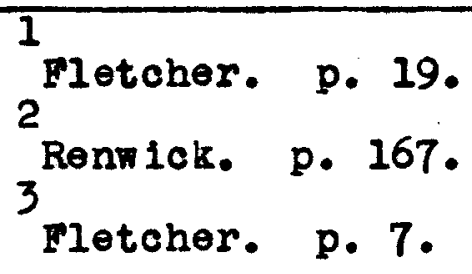


reality, a mere shadowing of that ultimate beauty, which exists only in the abstract. He goes farther, believing that there exists an incompatibility between flish and spirit, and that the ecstasy of spirItual experience can come only with the subordination and ultimate effacement of the flesh. The pleasure of the senseg then is to be counted as naught in comparison with the rapture of the soul. Those inatincts in man which excite in him passionate human attachments should be disciplined through consistent habits of restraint unt 11 they create in him that loftlest of all emotions, an insatiable longing for God. Thus only when the desire of sense leads to the ultimate gratification of the soul, are flesh and spirit reconciled. Herein 110 the Platonic conception that, first enamoured of earthly beauty, man 1s led gently, step by step, to behold the unspeakable glories of divine perfection.

Not only do the two philosophles agree in their conception of the relative importance of flesh and spirit, but also in their creation of the trinity of beauty, virtue, and love, which being three, nevertheless are one. For true beauty cannot be other than virtuous, and virtue must needs be beautiful, since each 18 a prototype of perfection. A man's 
being responds pleasurably to besuty, because it exudes the essence of virtue, as lovely flowers breathe out rare perfumes. That there exist in $11 f$ disorepancies between the good and the besutiful, that noble men sometimes lack comeliness, and evil men come masked in handsome faces, is not to be denled. The original blight of sin upon the earth has marred but not destroyed that perfect union of beauty and virtue, concelved of in the consclousness of God, or love.

In their estimate of human $11 f e$ and of man's purpose on earth, the two phllosophies also colncide. Man has come from God, and not unt1l he returns to Him will he be complete. Such then should be his a1m, to seek for a supreme emotional experience, counting all human loves but humble stepplng stones to that celestial love, which yearns to take unto itself his questing soul. Then only, in the consummate rapture of a heavenly wedlock, w1ll man have completed the cycle of his human $11 f e$, and be prepared to enter into the sublime experience of eternity.

There seem to be three fundamental similarities between these two phllosophies: first, a conviction that all physical forms are but the shadowings of spiritual realities; second, a bellef that the es- 
sences of beauty, virtue, and love are ultimately the same; third, a sublime falth that all sincere and holy human love 18 born of God and w111 lift man on wings of spiritual fervor up to the grandeur of lmmortality. These three ldeas pervade the discussions of Cardinal Bembo.

Consider first, his views concerning the relative importance of flogh and spirit. He belittles those "bequtles, which we dayly seo with these our dimme ejes in bodies subject to corruption, that neverthelesse be nothing els but dreames and most thinne shadowes of beaut 1e." ${ }^{1}$ He belleves that "the body, where that beautie shineth, is not the fountaine from whence beautie springeth", but rather the soul which "seeth in her selfe a shining beame of that light, which is the true 1mage of the Angel1ke beautie partened with (communicated to) her, whereof she also partneth w1th the bodie a feeble shadow." How inferior to the soul is this body, "a most diverse thing from beautie", which "1s bodllesse -an heavenly shining beame" and seen only "with the eyes of the minde." Therefore "who so thinketh in 1

All subsequent quotations appear in The Fourth Book of the Courtier, by Count Baldassare Castiglione, "Done Into English by Sir Thomas Hoby, Anno 1561". Everyman's Library. 
possessing the bodie to enjoy Beautle, he lo farre decelved", for he must "beholde it in it selfe simple and pure, and frame it within his imagination sundered from all matter". Then "he shall evermore carrle his preclous treasure about with him shutte past within his hart." It 18 only when one has "waxed blinde about earthly matters" that he "1s made quicke of sight about heavenly." When he has achleved this new vision he ls beholding "the true monument -- of the victory of the soule." He has seen the light whlch "overcommeth the darknesse of the bodie", which "destroyeth and consumeth whatsoever there is mortall, and relleveth and maketh beautifull the heavenly part, which at the first by reason of the sense was deade and burled." Fervent, suppliant, rises the prayer of the Cardinal: "(Lord), Purge with the shining beames of thy light our ejes from mistie ignorance, that they may no more set by mortall beautie."

None the less Platonic in spirit are Bembo's words concerning the origin and meaning of beauty, virtue, and love. He relterates his bellef in the unity of beauty and virtue. "Good and beautifull be after a sorte one selfe thing." Again, "beautie 1s good, and consequently the true love of it is most good and 
holy." And again, "whatsoever is good and profitable hath also evermore the comelinesse of beautie." Is not this evidenced in "the besutie of the buddes (which) glveth a testimonle of the goodnesse of the fruiti" Love also is closely assoclated with beauty, since "Love is nothing else but a certaine coveting to enjoy beautie." And of necessity must love be one with virtue since it is "the beginning and end of all goodness." As for the origin of beauty, it "commeth of God." Man's delight then in boholding 1ts physical manlfestation can readily be explained in the light of 1ts divine origin. "What sweete incense may a man belleve that to be, which arleeth of the fountaine of the soveralgne and right beautieg" Man is in reality contemplating a form of "heavenly beautie (which 18) the originall of all other beautie, whlch never encreaseth nor diminlsheth."

Cardinal Bembo does not fall short of Platonic heights in his impassioned declaration of the gospel of immortality. Man's emotional life upon earth, if kept pure, will culminate in a heavenly ecstasy. It is the instinct of love forever springing up within the heart of man that is "a meane betwixt heavenly and earthly thinges." It "1s the flery bugh of Moses", the flame which having lasued from the heart of God, 
kindles the fuel of the human soul. This first stirring of warmth within the human heart is usually prompted by physical beauty, since holy love "delightest to dwell in the floure of beautifull bodies and beautifull soules." In this presence of physical beauty the soul "feeleth the feare and reverence that men accustomably have towarde holy matters, and thinketh her selfe to be in Paradise", for man "through the vertue of Imagination, shall fashion with himselfe that beautie much more faire than it is in deede." Man must take care, however, that in his admiration he "love no lesse - - the beautie of minde, than of the bodle" and in his tenderest caressings he lose not sight of "Plato, the divine lover, (who) saith, that in klssing, his soule came as farre as his lippes to depart out of the bodle." The lover must always renember that "a k1sae may be saide to be rather a coupling together of the soule, than of the body." If a man shall achleve love's full experience then, he will keep "aloofe from sensuall coveting as fro the lowest atep of the stayres, by the which (he) may ascend to true love." He w11l "shunne throughly al filthinesse of common love, and so enter into the holy way of love, with the guide of reason", for it is by "understanding (that) man may be partner with angels." 
Then "the lover shall find another (love) yet farre greater, in case hee 111 take this love for a stayre (as It were) to climbe up to another farre blgher than 1t." Younting a stairway of emotional experience, the lovér "shall beholde no more the particular beautle of one woman, but an universal, that decketh out all bod1es." And "11ke as through the particular besutie of one bodie hee (love) guldeth her (the soule) to the universall beautie of all bodles: Even so in the least degree of perfection through particular understanding hee (love) guldeth her to the universal understanding." Fervently Cardinal Bembo relterates the theory of the soul's glorious ascension as "burning in this most happle flame, she ariseth to the noblest part of her which is the understandIng, and there no more shadowed with the darke night of earthly matters, seeth the heavenly beautio." How supreme is the achievement of this human lover who has overcome fleshly desires "that h1s soule may be ravished through heavenly love to the beholding of heavenly beaut 1e" where "having founde -- the footsteps of God -. she seeketh to settle her selfe" and remaine eternally "coupledat with God". Earnestly Cardinal Bembo exhorts his listeners to strive for this spiritual union, "putting off the 
affections we were clad at our coming downe let us climbe up the stalres, which at the lowermost steppe have the shadow of sensuall beautie, to the high manaton place where the heavenly, amiable and right beautie dwelleth, which lyeth hidden in the innermost secreties of God." Reaching a majest1c crescendo of emotional fervor, he invokes the assiatance of God: "Burne them (our soules) -- that after they be cleane sundred from the bodie, they may bee coupled with an everlasting and most sweet bond to the heavenly beaut1e."

In attempting to trace the influence of Plato upon Elizabethan poetry, one cannot ignore this new Platonism which became so inter-mixed with the old. "In all likelihood Spenser's Hymns of Heavenly Love and Hewvenly Beauty are derived from Bembo's oration in this Book of the courtier. Shakespeare's Sonnets show something of the same influence",

\footnotetext{
1

Henderson, W. B. D. A Note of Castiglione and
} Engligh Literature. The courtier. p. XIII. 
CHAPTER III

EDMUND SPENSER

-

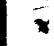

$+$ 


\section{CHAPTER III}

\section{EDMUND SPENSER}

"In no poet did the mystioal interpretation of the Platonic idea come more beautifully and clearly to make its avatar than in Spenser." ${ }^{1}$ He is generalIf accepted to be the outstanding Platonic poet of the Elizabethan age. H1s Fonre Hymnes repeatediy confirm in the minds of his crities the fact that he was a student and a follower of Plato's theory of love and beauty. "Spenser's Hymnes are the most comprehensive exposition of love in the light of Platonic theory in English." And yet there are some who hold that Plato'g Influence upon Spenser has been over-emphasized and that the philosophical bent of his mind bespeaks a varlety of sources rather than one. "A fragment of -- Plato may be borrowed, not only for 1ts beauty, but because it expressed more or less clearly some feding which spenser was trying to make explicit -- The use of quotations may be proof of etudy, but is not necessarily proof of intellectual disc1plesh1p, st1ll less of complete accoptance of a system of thought. -- Plato contributed

Cory, H. E. Edmund Spenser. p. 353. 2

Harrison, J. S. Platonlsm 1n English Pootry. p. 122. 
largely to Spenser's thought, but he was not the on1y source of principle, nor was he the final author1 ity." With no intention then of exaggerating spenser's indebtedness to Plato, I shall merely point to those passages in his Fowre Hrmnes, which seem most obviousig to be the sincere utterances of a Platonic lover.

In An Hymne in Honour of Love Spenser explaing the parentage of love as does Dlotima to Socrates in the srmpos 1um.

"---who al1ve can perfectly declare, The wondrous cradie of thine infancie? When thy great mother venus first thee bore, Begot of Plentie and of Penurie" (11.50-53)

In suberquent lines he develops the ldea that love' heritage of Penurle has given it a starving need which can not be supplied. And though, through Plent 1e's ingenuity the lover does recelve the image of that which he craves, yet Penurie keeps him forever dissatisfied.

"He thereon feeds his hungrie fantasy st1ll full, yet never satisfyde with 1t." (11.198, 199) The polgnancy of his longing incites in him a frenzy akin to Platonic "madness" experlenced by all such lovers, who

"-.- playne and make ful piteous mone Unto the author of their baleful bane; The dales they waste, the nights they grleve and grone, Their lives they loath, and heavens light disdaine,

Renmick, N. L. Eamund Spenser. pp. 154, 167. 
No 11ght but that, whose lampe doth jet remaine Fresh burning in the image of their eye, They delgne to see, and seeing it still dye."

(11. $127-133$ )

Since love is born of Resource, it goada the agltated lover to perform any task, encounter any peril, in order to appease his unutterable longing.

"He dreads no danger, nor misfortune feares, H1s faith, his fortune, in his breast he beares. Thou art this god, thou art his mightie gjde, Thou being blind, letst him not see his feares, But carlest him to that which he hath eyde, Through seas, through flemes, through thousand swords and speares:

Ne ought so strong that may his face withatand, With which thou armest his resistlesse hand."

(11. 223-230)

There is but one thing that can excite in a 10v-

er such superlative enthus lasm and that is beauty.

"For sure of all, that in this mortall frame Contained 18, nought more divine doth seeme, Or that resembleth more th' lmmortall flame of heavenly light, then Beautieg glorlous beame. What wonder then, if with such rage extreme Fraile men, whose ejes seek heavenly things to ser, At sight thereof so much enravisht bee?"

(11. $113-119$ )

But it 18 not the mere contemplation of beauty that the Spenserian lover $\mathbf{1 s h e g}$, and herein does he become Platonic; he desires birth in beauty; he desires to beget 11fe, not to gratify a beastial lust but to achleve immortality.

"-.-- man, that breathes a more immortall nynd, Not for lusts sake, but for eternitie, seekes to enlarge his lasting progenle Therefore in choice of love, he doth desyre 
That seemes on earth most heavenly, to embrace, That same is Beautie, borne of heavenly race."

(11. 103-112)

His desire is an ennobling impulse in no way to be assoclated with that "Popular" love of which Pausanias speaks with such contempt: "the love we see in the meaner sort of men who are set on the body more than the soul." ${ }^{1}$ Such is not Spenser's Iove,

"For love is Lord of truth and lolaltie, Lifting himselfe out of the lowly dust, On golden plumes up to the purest skie, above the reach of loathly sinfull lust.

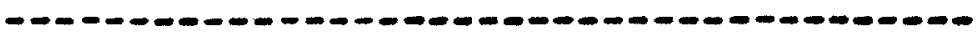

Such 18 the poure of that sweet passion, That it all sordid basenesse doth expeli." (11. 176-179; 190,191)

As Plato belleved, so does spenser, that the lover's desire 18 quickened by the sight of beauty incarnate in some individual; the only point upon which they differ being that, whereas Plato looked for his inspiration to a beautiful youth, Spenser looks to a beautiful moman.

"His harts enshrined saint, his heavens queen, Falrer then falrest, in his fayning eye, Whose sole aspect he counts fellcitye."

(11. 215-217)

In Amorett1, Sonnet III, he is inspired to noble purposes by a beautiful woman, whose charms hold his mind in a kind of ecstatic trance.

"The soverayne beauty which I doo admyre, Witnesse the world how worthy to be prayzed: The light wherof hath kindled heavenly fyre, In my fraile spirit by her from basenesse raysed. 
That being now with her huge brightnesse dazed Base thing I can no more endure to view: But looking st111 on her I stand amazed, At wondrous sight of so celestiall hew. So when my toung would speak her praises der, It stopped is with thoughts astonishment: And when my pen would write her titles true, It ravisht is with fancies wonderment. Yot in $\mathrm{my}$ hart I then both speake and write The wonder that my wit cannot ondite."

Furthermore, Spenser believes with Plato that the lovor's ablilty to discriminate between true and false beauty remains as his heritage from a former spiritual existence, when the soul of man boheld in its ontirety the vision of eternal beauty.

"For having get in his deducted spright, Some sparks remaining of that heavenly fyre, He is enlunined with that goodly 11ght, Unto like goodiy semblant to aspyre." (An Hymne in Honour of Love. 11. 106-109)

In An Hymne in Honour of Love Spenser takeg the Platonic lover's first step. He goes no farther. H1s des1re, he belleves, $\mathbf{1 1 1}$ be fully appeased when

(1 in her inmost breast, He may embosomed bee, and loved best." Ay me, deare Lord, that ever I might hope, For all the palnes and woes that endure, To come at length unto the wished scope of my desire." (11. 248,249; 294-297)

For him "Iove as in the Srmposium is as a clarion that calls to heroic questing the ardent lover", but he would seek no farther than a woman's arms. An Hymno in Honour of Beautie 18 a natural com1 cory. p. 337 . 
plement to An Hymne in Honour of Love since the poet belleves beauty to be the sole insplration of love.

"That is the thing which giveth pleasant grace To all things falre, that kindloth lively fyre, Light of thy lampe, which ahyning in the face, Thence to the soule darts amorous desyre."

(11. $57-60$ )

Spenser accepts the theory of Plato concerning the ult imate source of all earth-born beauty, which is a divine Pattern or eternal Idea existing apart as a purely spiritual entity.

"That wondrous Paterne wheresoere it bee, Whether in earth layd up in seoret store or else in heaven, that no man may it se0 With sinfull eyes, for feare it to deflore Is perfect Beautie which all men adore, Those face and feature doth so much excell All mortal sence, that none the same may tell." (11. 36-42)

He "harmonizes Floino's notion that beauty is the 'Iively grace' of God's light with the brilliant theory of Plato in the Imaeus that beauty 18 a great unchangesble pattern from which the supreme Artificer modeled the world."

"What time this worlds great workmalster did cast To make al things, such as wo now bohold, It seemes that he before his eyes had plast A goodly Paterne, to whose perfect mould He fashloned them as comely as he could." (11. 29-33)

According to Taine spenser considers beauty not "a mere harmony of color and form, but an emsnation of unique, heavenly, Imperishable beauty, which no mor1 Cory. p. 339. 
tal eje can see, and which is the masterplece of the great Author of the worlds. Bodies only render it visible; it does not live in them; charm and attraction are not in things but in the immortal 1dea which ohines through them."

"For through infusion of celestiall poure; The duller earth it quickneth with delight, And 11fe-full opirits privily doth powre Through all the parts, that to the lookers slght They seeme to please. That is thy soveraine might o Cyprian queene, which flowing from the beame of thy bright starre, thou unto them dost streame." (11. 50-56)

In smorett1, Sonnet LXXIX, the lover stresses not the physlcal charms of h1s beloved but the true and permanent beauty of her epirit.

"Men call you falre and you doe credit it, For that jour selfe je dayly such doe see: But the trew fayre, that is the gentle wit, And vertuous mind, is much more praysd of me, For all the rest, however layre it be, Shall turne to nought and loose that glorlous hew: But onely that is permanent and iree From frayle corruption, that doth flosh ensew. That is true beautie: that doth argue you To be divine and borne of heavenly seed: Deriv'd from that fayre Spirit, from whom al true And perfect beauty did at first proceed. He onely fayre, and what he fayre hath made,"

There is a mysterious element in beauty, too subtle to be detected by the eye.

"That Besutie is not, as fond men misdeeme, An outward show of things that onely seeme." (An Hymne in Honour of Beauty. 11. 90,91 )

The poet accounts for man's innate capacity to appre1 book 2. p. 132 .

Taine, H. A. History of English Literature. 
clate beauty by the Platonlc theory of reminiscence, whereby the soul recalls "those pure, true, and beautiful Ideas which it had partially seen during its prior extra-corporeal existence in companionship with the Gods", 1 before 1t

"...

Downe from the top of purest heavens hight, To be embodied here" (11. 108-110)

Earthiy love he conceives of as but a continuation

of an affection which once existed between soul and soul.

"For love is a celestiall harmonie, of likely harts composed of starres concent, Which joyne together in sweete sympathie, To worke esch others joy and true content, Which they have harbourd since their first descent Out of their heavenly bowres, where they did see and know ech other here belov'd to bee."

(11. 197-203)

The tendency then of the earthly lover is to construct about hls loved-one a halo of splritual perfection since "the mind remembers, even though half-numbed, by the flesh, the only half-forgotten beauty it once contemplated in heaven." ${ }^{2}$ He does not in reality admire the woman upon whom he so rapturously gazes, but rather he unittingly admires the celestial vision which her presence recalls.

"Of that first sunne, yet sparckling in his slght, Thereof he fashions in his higher skill, An heavenly beautio to his fancles will And it embracing in his mind ontyre

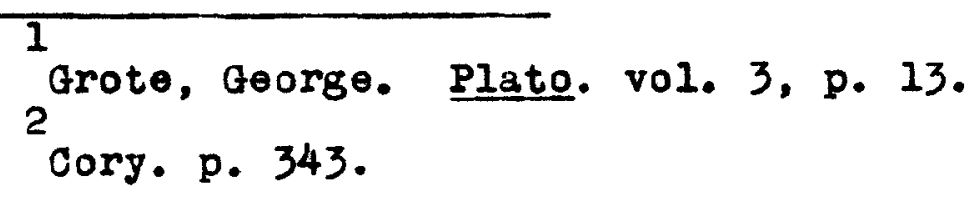


The mirrour of his owne thought doth admyre."

(11. 220-224)

These IInes "carry us into pure Renaissance Platonism."

Lovely women are but lmages of heaven's light.

"-.--ye Paire Dames, the worlds deare ornaments, And ilvely images of heavens light,

Be mindfull still of your first countries sight, Doe still preserve your first informed grace, Whose shadow yet shynes in your beauteous face." (11. 162-168)

The Platonic theory that the beautiful is also

the good leads the poet disastrousiy to associate no-

bility of character with perfection of body.

"Therefore where ever that thou doest behold A comely corpse, with beautio falre endewed, Know thls for certaine, that the same doth hold a beauteous soule, with falre conditions thewed, Fit to recelve the seede of vertue straved. For all that falre 1a, is by nature good." (11. 134-140)

But his own resson cannot deny the apparent discrepaney of such a bollef when

"--.--oft it falles, that many a gentle mynd Dwels in deformed tabernacle drownd

And oft it falles (ay me the more to rew) That goodly beautie, albe heavenly borne, Is foule abused" (i1. 141,142; 148,-150)

Yet our intrepid Platonist 111 admit no inconsistencies here, preferring in each instance to deplore the atubborn qualities of an unylelding flesh, rather than to admit the deficlencies in a Platonic theory. 1 Cory. p. 343. 
At the close of an Hymne in Honour of Bequt1e, Spenser has ascended no higher the stairway of Platonic love. Beauty for him 1s still incarnate in one human form and hls desire seeks its rellef in her,

"-.--Those conquering besut 1e doth captive yy trombling hart in her eternall chaine."

(11. 275, 276)

And now as we pass from earthly love to heaven1y, from sensuous beauty to spiritual, "we touch (with Spenser) the sublime, sharp summit where the world of mind and the world of sense unite; where man, gathering with both hands the lovellest flowers of either, feols himself at the same time a pagan and a Christian." The fact that Spenser's last two hymno were written much later in 1 ife confirms the theory of Plato that love is a process of development, marked by the growing intensity of a lover's desire and the quickening of his response to spiritual realities. Love for Spenser is no longer a physical yearning for beauty manifest in feminine cheok and breast, for "hls was a soul captivated by sublime and chaste beauty, eminently Platonic; one of those lofty and refined souls, most charming of all, who, born in the lap of nature, draw thence thelr sustenance, but soar higher, enter the regiong of mysticism, and mount instinctively in order to expand on the confines of a 1

Talne. book 2, p. 133. 
loftier world." His desire now is a straining of the soul to be freed from the flesh.

"Love, 11ft we up upon thy golden wings, From this base world unto thy heavens bight, Where I may see those admirable things, Which there thou workest by thy soveraine might, Farre above feoble reach of earthly sight, That I thereof an heavenly Hymne may sing Unto the god of Love, high heavens king."

(An Hymne of Heaveniy Love, 11. 1-7)

This straining at the body's leash can be noted also in Amorett 1, Sonnet LXXXVIII. Unable to satisfy his senses, the poet has recourse to a contemplation of the heavenly spirit of her whose physioal presence 18 denled him.

"Since I have lackt the comfort of that light, The which was wont to load my thoughts astray: I wander as in darkenesse of the night, Affrayd of every dangers least dismay. Ne ought I see, though in the clearest day, When others gaze upon theyr shadowes vayne: But th'onely image of that heavenly ray, Whereof some glance doth in mine ele remayne of which beholding the Idea playne, Through contemplation of my purest part: With light thereof I doe my selfe sustayno, And thereon feed my love-affamisht hart. But with such brightnesse whylest I fill my wind, I starve my body and mine eyes doe blynd."

Cory observes with a pardonable lack of enthuslasm the passing of our lover away from this earth, whose varlous forms took on new beauty when touched by the transforming wand of his melodic, sweetly sensuous verse. "One need not be a mere literary man under suspicion of irresponsible hedonism to feel some sense of regret as Spenser passes on to an uncompromising 
Platonic mysticism" in the last two hymns where "the ascet1c side and the antinaturalism of Plato dominate." Spenser's renouncing of the world, however, is not a solely Platonic inspiration,. for "the Bible of all books was his principal source, as it was the foundation of his faith." ${ }^{2}$ The charm of Platonism for spenser 1108 in 1ts easy adaptability to Christian themes. He effects "a perfect tempering of Christian and pagun synbols." 3 Plato's theory that love is a desire for birth in beauty is deftly used spenser to explain the mystic relationship existing between a heavenly Father and a divine son. Diotima defines love as an "engendering and begetting upon the beautiful", and "hence It is that when the pregnant approaches the beautiful it becomes not only graclous but so exhllarate, that 1t flows over with begetting and bringing forth." It was this elemental desire, this divine love or Christian God that brought forth the Messiah of the New Testament.

"It lov'd 1t selfe, because it selfe was faire; (For faire 18 lov' $d$ ) and of it selfe begot Like to it selfe his eldest sonne and helre, Eternall, pure, and volde of sinfull blot, The firstiling of his joy, in whom not jot

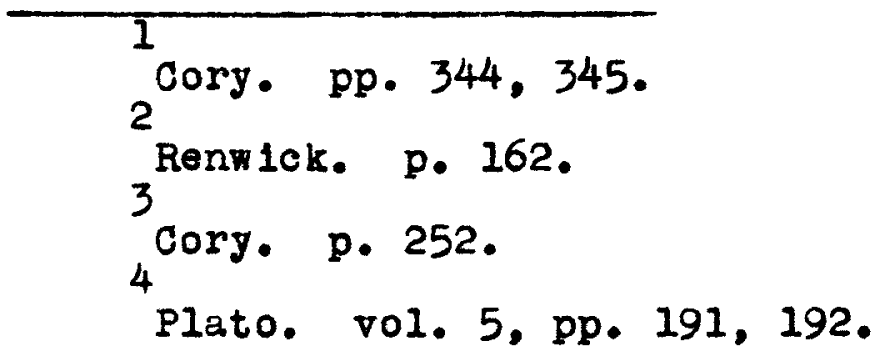


of loves dislike or pride was to be found, Whom he therefore with equall honour crownd."

(11. 29-35)

Following the same concelt, spenser accounts for the origin of the angelo.

"Yet being pregnant st11l with powrefull grace, And full of fruitfull love, that loves to get Things like himeelfe, and to enlarge his race, His second brood though not in powre so great, Yet full of beaut1e, next he did beget An infinite increage of Angels bright, All glistring glorious in the ir Makers ilght." (11. 49-56)

It is the breath of God which first quickened dull clay into human 11fe, and gave to man a beauteous countenance, peculiarly divine.

"Therefore of clay, base, vile, and next to nought, Yet form'd by wondrous sk111, and by his might: According to an heavenly patterne wrought, Which he had fashioned in his wise foresight, He man did make, and breathed a living epright Into his face most beautifull and fayre Endered with $\mathbf{1 s e d o m e s}$ rlches, heavenly, rare. Such he him made, that he resemble might Himselfe, as mortall thing immortall could." (11. 108-114)

At the close of the third hymn spenser has ascended far up the ladder of Platonic love, albelt on the rounds of Christian belief. His desire now cleaves to the divine personality of the Son; the pange of spiritual poverty stab through his starving, yet ascendent soul.

"Then shalt thou feele thy spirit so possest, And ravisht with devouring great desire of his deare selfe, that shall thy feeble brest Inflame with love, and set thee all on fire 
With burning zeale, through every part entire, That in no earthly thing thou shalt delight, But in his sweet and amtable glght." (11. 267-273)

He 1 freed from the bondage of the obvious, for his senseg have been quickened to percelve a spiritual body.

"Thenceforth all worlds desire w11l in thee dye, And all earthes glorie on which men do gaze, Seome durt and drosse in thy pure sighted eje, Compar'd to that celestiall beauties blaze, Whose glorious beames all fleshly sense doth daze With admiration of their passing light, Blinding the oyes and lumining the spright."

(11. 274-280)

The climax of Platonic love is reached with the closing Iines. Fith a vision of the Ides of pure glory, desire within the soul reaches its most exquisite need.

"Then shall thy ravisht soule inspired bee Fith heavenly thoughts, farre above humane skil, And thy bright radiant oyes shall plainely see Th'Idee of his pure glorie, present st11l Before thy face, that all thy spirits shall fill With sweete enragement of celestlall love, Kindled through sight of those faire things above." (11. 281-287)

Heavenly love 1o inspired by a revelation of heavenly beauty,

"Through contemplation of those goodly sights Whose wondrous beauty breathing sweet delights Do kindle love in high concelpted sprights." (An Himne of Hearenly Beaut10. 11. 2-4) The opening Ilnes of the last hymn bespeak a Platonic lover whose ravished vision is blurred by his first glimpse

"Of that Immortall beautio

Fhich in my weake distraughted mynd I see." (11. 13. 14) 
He has been mount ing the rounds of the ladder of love,

"Beginning then below, with th'easie vew of this bese world, subject to fleshly eye, From thence to mount aloft by order der, To contemplation of th' Immortall sky. of the soare fauloon so I learne to $\mathrm{fly}$. That flags awhile her fluttering wings beneath, Till she her selfe for stronger filght can breath." (11. 22-28)

The poet at flrst does not wholly lose sight of earth-

ig beauty in his glorifleation of heavenly beauty.

He is too sensitive to 1ts charms for that. For him st111 "the hearens declare the glory of God; and the firmament sheweth his handymork."

"The meanes therefore, which unto us 1s lent, Him to behold, is on his workes to looke, Which he hath made in beauty excellent, And in the same, as in a brasen booke, To reade enregistred in every nooke His goodnesse, which his beautie doth declare, For all thats good, is beautifull and faire." (11. 127-133)

But these outward forms depict to the dulled vision a beauty, which is far surpassed as it

" doth upward tend, And further 18 from earth, so at 111 more cleare And faire it growes, till to his perfect end of purest beautie, it at last ascend."

(11. 44-47)

This celestial beauty finally appears in

A of the divine eternall majestie;

More falre 1s that, where those Ideas on hie, Enraunged bo, whlch Plato so admyred And pure Intelligences from God inspyred."

(11. 80.84)

Spenser never loses slght of the good in his worship 
of the beautiful, for although "sensuous beauty is perfect in both (Spenser and Plato) their maln worship is for moral beauty." The beauty of God's very presence is surpassed by the perfection of His moral excellence,

"His truth, his love, his wisedome, and his blis, H1s grace, his doome, his mercy, and his might, By which he lends us of himselfo a sight."

(11. 109-111)

Spenser "has succeoded in selzing bequty in 1ts fulness, because he cared for nothing but beauty." 2 of the many who are actuated to take the firat halting steps in the mysterles of Platonic love, fow achleve "the highest pitch of philosophlcal love, when the mind has ascended to the contemplation of beauty in genere, not merely in bodies and minds, but in laws, institutions, and sciences." ${ }^{3}$ Spenser is one of the fer who has caught a vision of the divine Intelligence.

"There in God's bosome saplence doth sit, The soveraine dearling of the Deity."

(11. 183, 184)

"According to Spenser -- heavenly love is the love felt in the soul when the slght of wisdom in her beauty darns upon the inner vision. It is a love gained through speculation." And he easily blends with Pla-

1

Talne. book 2, p. 132 .

2

Ib1d. p. 137 .

3

Grote. vol. 3, p. 7

4

Harr 1son. p. 75. 
tonism the Calvinistic doctrine of election, for none can behold eternal W1sdom save those to whom she has chosen to reveal herself.

"None thereof worthy be, but those whom shee Vouchsafeth to her presence to receave, and letteth them her lovely face to see."

(11. 253-255)

And now the lover 18 prepared to recelve his reward, a complete provision for the starving needs of his moral and spiritual being. The sight of pure Intelligence has effectually remored what clods of earth may yet have clung to him in his arduous ascent. Ho is now numbered among those Platonic lovers who are onjoying such

H...- sweete contentment, that it doth bereave Their soule of sense, through infinite delight, And them trangport from flegh into the spright." (11. 257-259)

And here we shall leave him in his trlumph, with his pure soul beholding

"-...-.- that soveraine 1ight, From whose pure beams al perfect beauty springs, That kindleth love in every godly gpright, Even the love of God." (11. 295-298)

1 P. 119.

Fletcher, J. B. The Religion of Beauty in Woman. 
CHAPTER IV

VILLIAY SHAKESPEARE 
CHAPTER IV

WILIAY SHAKRSPRARE

T1lliam Shakespeare 1o a Platonic lover. True, he does not, with methodical zeal, purpose to set forth in his sonnet sequence a luold interpretation of the Platonic doctrine. It 18 Spenser who expounds the theory with meticulous care. But shakespeare is conversant with the philosophy of his time; he has no doubt read Spenser's Fonre Hymnes and Hoby's The Courtier; he possesses a nature sensuous and passionate enough to rejolce in all the multifold forms of natural beauty, and, at the same time, spiritual enough to extract out of thls objective beauty an essence of etermal verity. Shakespeare does not go the whole way with Plato, for we do not find him grown to love abstract Idea as fondly as he does the person of that comely Elizabethan youth to whom he addresses his sonnets. And yet to this extent is he a Platonic lover, that "In the impassioned glow of his conceptions, the material and the spiritual are blent and fused together."

In his infatuation for a youth rather than for

\footnotetext{
1 p. 362 .

Tyndham, George. Essa7s in Romant ic Literature. 2

Pater, Nalter. Plato and Platonism. p. 121.
} 
a maid, Shakespeare is pecullarly Platonic, for the Greok phllosopher or lover, attached himself to a young man of promise, whose physloal perfection and mental alertness, combined to satisfy the clamorous destres of sense as well as of soul. The Greek women were married young; they knew little more than the art of spinning and weaving. That their beauty provide for their husbands a sensual sat1sfaction was all that was expected or desired of them. The man of intelleot as well as passion must look elsewhere for a fully congenial companionship. And he turned to some handsome and aspiring boy of noble birth. "It was the masouline beauty of youth that fired the Hellenic imagination with glowing and Impassioned sentifient. " ${ }^{1}$ Although much that is beaut1ful in Elizabethan poetry has been inspired by moman, Shakespeare, I1ke a sixteenth century Socrates, becomes enamored of a falr young man. In Sonnet XX he describes him as having all the graces of a woman, yet none of her short-comings; he would reserve for himself the real affection of this youth and, in the event that the young inan wed, leave for his wife the remnants of a merely physical attachment.

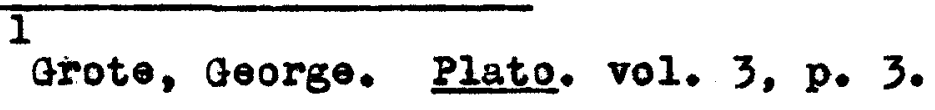


"A woman's face with Nature's orn hand painted Hagt thou, the master-mistress of my passion; A moman's gentle heart, but not acquainted With shifting change, as is false woman's fashion. An eye more bright than theirs, less false in rollieg, Gllding the object whereupon it gazeth; $A$ man in hue, all 'hues' in his controling, Which steals men's eyes and women's souls amazeth. And for a woman wert thou first crested. -

Mine by thy love, and thy love's use their treasure." according to Plato, the joy of Int imate human association is not an end in 1tself. The physioal, intellectual, and moral beauty of a youth is to provide the philosopher with a stimulus which will ultimately enhance his powers of profound thought and spiritual perception. In the Phoedqus, Eros or love 18 "mad, irrational, superseding reason and prudence In the individual mind." And before a philosopher can catch a vision, a revelation of divine essences, he must become fired with an enthuslasm which is akin to madness. The sober, right-thinking, decent cltizen, no matter hov meritorlous his 11 fe may be, w11l never develop into a Platonic lover. "The greatest blessings enjoyed by man arise from madness, when it is imparted by aivine inspiration. " ${ }^{3}$ It is important to remember, of course, that a madness sprung from any but divine sources $w 111$ result in untold evil.

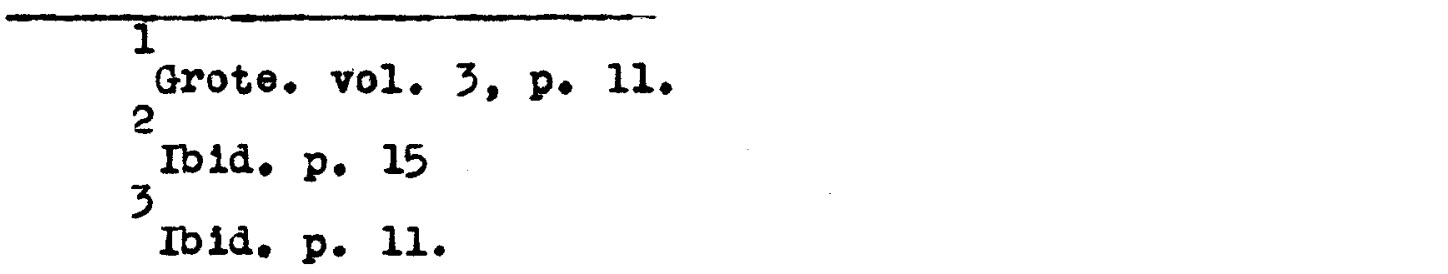


In accordance with Plato's theory of reminiscence, "the contemplation of a beautiful youth, and the vehement emotion accompany ing 1t, was the only way of reviving in the soul the Idea of Beauty which it had seen in its antecedent stage of existence." 1

Herein, again, do we see Platonic tendencies In Shakespeare, for he invests his youth with a glamorous wonder that could be seen only through the eyes of a frenzled enthuslast. In fact, Shakespeare may be temporarily termed "mad". H18 senses respond to beauty in no form save in the person of his beloved youth.

"For summer and his pleasures walt on thee, And, thou away; the very birds are mute; or, if they sing, 'tis with so dull a cheer That leaves look pale, dreading the winter's near." XCVII.

He ascribes all his literary power to the inspiration of the young man's wondrous eyes, which are the teachers alike of $\mathbf{1} 18 \theta$ and foolish.

"Thine ejes that taught the dumb on high to sing, And heavy Ignorance aloft to $11 y$, Have added feathers to the learned's wing And given grace a double majesty. But thou art all my art and dost advance As high as learning my rude 1gnorance." LXXVII. Consclous that sane readers of his verse w11l not consider plausible h1s wild assertions, he bemoans 1 Grote. vol. 5, p. 4. 
the coming generation's skept101sm.

"If I could write the beauty of your ejes And in Presh numbers number all your graces, The age to come would say 'Th1s poet 11es, Such heavenly touches ne er touch'd earthiy faces." " XVII.

The personality of his friend has so invigorated him that in moments of mental depression he has but to think on him for consolation.

"Yet in these thoughts myself slmost desplsing Haply I think on thee, and then my state, Like to the lark at break of day arising From sullen earth, sings hymns at heaven's gate." XXIX.

We find this same power residing in the friend in Sonnet XXX.

"--.--1f the while I think on thee dear friend, All losses are restored and sorrows end."

Dlotima says to Socrates, "The man who does not feel himself defective has no desire for that whereof he feels no defect." Nowhere is the consclousness of defect more forclbly impressed upon the lover than In the presence of that friend, whom he has invested With a rare perfection. Herein then 1108 the frlend's real service to the lover. A sense of defect is created in the lover's consclousness, out of which rises an absorbing desire to possess that good which resides outside of himself. And so he makes a gesture toward a fond 1deal. The intensity of his desire, and 1ts nature, will determine just how far 1 Plato. vol.5, p. 183. 
he will go into the realm of mystic philosophy, but he is to some degree a Platonist as soon as his love becomes "a state of consclous want, and of aspiration or endeavor to satisfy that want, by striving after good or happiness." "Shakespeare is acutely aware of h1s own unworthiness in sonnot LXXII.

"O, lest the world should task you to recite What merit lived in me, that you should love, After my death, dear love, forget me quite, For you in me can nothing worthy prove; Unless you mould devise some virtuous 110 , To do more for me than mine own desert, And hang more pralse upon deceased I Than niggard truth would willingly impart."

Th1s Platonic "madness" which has tipped the poet's wings with strong desire and sweet humility leade him quite naturally into another region of Platonle thought. His prolonged contemplation of his friend's perfections has resulted in the mergins of his own personality into that of his frlend. He becomes identified with his friend; they have become one. "The concelt of Identity with the person addressed 1s but a part of the machinery of Rena1ssance Platonics, derlved, at many removes, from discussions in the Platonic Academy at Florence." Pausanias in the Symposlum says that "the lover of a nature that is worthy abides throughout ilfe, as belng fused into one nith the ablding." ${ }^{3}$ Grote ex-

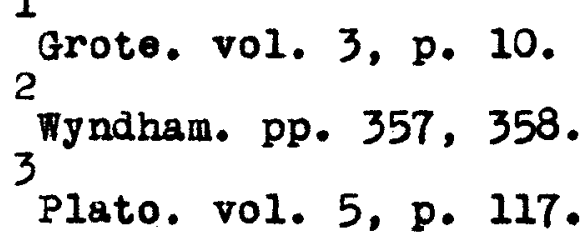


plains that "the lover did not merely admire the person, but also contracted the stronisest sympathy with the feelings and character of the beloved youth." ${ }^{1}$ Shakespeare expresses this idea in various degrees of fanciful conceita throughout a number of h1s sonnets.

"But here's the joy; my friend and I are one." XLII.

"-..- thou art al1 the better part of me." XXXIV.

"As easy might I from mjself depart As from my soul, which in thy breast doth 11e." C IX.

In sonnet XXII he concelves of himself as being no older than his young friend because of his ldentity with him.

"My glass shall not persuade me I am old, So lons as youth and thou are of one date; But when in thee time's furrows I behold, Then look I death my days should explate. For all that beauty that doth cover theo Is but the seemly raiment of my heart, Which in thy breast doth live, as thine in me. How can I then be older than thou art?"

He knows no physical blemish, no poverty, no unpopularity so long as he may find beauty, wealth, and honor in the possession of his friend.

".... whether beauty, birth, or wealth, or wit, Or any of these all, or all, or more Entitied in thy parts do crowned sit, I make my love engrafted to this store: So then I am not lame, poor, nor despised, Whilst that this shadow doth such substance give 
That I in thy abundance am sufficed And by a part of all thy glory live."

XXXVII.

He becomes gullty of self-love, since to love his

friend of whom he is a part, means that he is in ef-

fect loving himself.

" In of self-love possesseth all mine eye And all my soul and all my every part; and for this in there is no remedy, It is so grounded inward in my heart. Methinks no face so graclous is as mine, No shape so true, no truth of such account; And for myself mine own worth do define, As I all other in all worths surmount. But when my glass shows me myself indeed, Beated and chopp'd with tann d antiquity, Mine own self-love quite contrary I read; Self so self-loving wero inlquity. Tis theo, myself, that for myself I praise, Painting my age with beauty of thy daye." LXII.

Even in death the lover remains ldentified with his erlend through the spirit which has produced his verses. The body's decay cannot destroy the spiritual union which has made them one, and which is reestablished each time the friend rereads the poet's ilnes.

"But be contented. When that fell arrest

- Without all ball shall carry me away, Ny life hath in this line some interest, Which for memorial still with thee shall stay. When thou reviewest th1s, thou dost review The very part was consecrate to theo: The earth can have but earth which 18 his due; My spirit is thine, the better part of me: So then thou hast but $108 \mathrm{t}$ the aregs of $111 \mathrm{fe}$, The prey of morms, my body being dead, The coward conquest of a mretch s knifo. Too base of thee to be remembered. The worth of that is that which it contains And that is this, and this with theo remains." LXXIV. 
A popular form of Renalssance Platonism dealt with the theme of ldeal beauty. Plato's theory of beauty had passed through many intermediarles before reaching Shakespeare: from Byzantlum 1t had come to Florence, and from thence to England and France. Plato concelved of visible beauty as a representative of an invisible beauty, which existed in the realm of universal 1deas. "If any man's vision be once sharpened so that he can see beauty pure and absolute, he will have no eges for the individual manifestations of it in gold, fine ralment, brilliant colours, or beautiful youths. Herein we have the climax" of Platonic love. Renaissance Platonlsm often inverts this theory, 28 does shakespeare in his sonnet sequence. Instead of beholding in his frlend the medium through which he can catch a superb vision of ldesl beauty, he sees no farther than this human form, which, in itself is beauty's complete revelation. His frlend is not patterned after the eternal 1dea of beauty; but rather embod1es in himself that pattern which Nature, in each new and exquisite aspect, imitates.

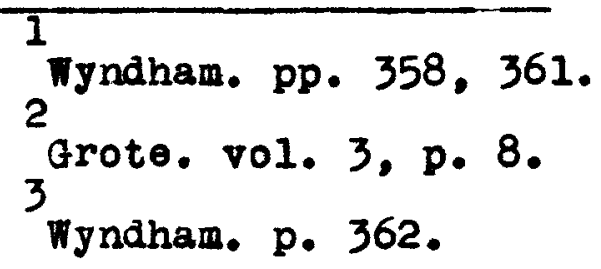


"Nor did I wonder at the $111 \mathrm{y}$ 's white, Nor praise the deep vermilion of the rose; They were but sweet, but flgures of delight, Drawn after you, you pattern of all those. Yet seem'd it winter st111, and you away, As with your shadow I with these did play."

XCVIII.

Again

"More flowers I noted, yet none I could see But sweet or colour it had stol'n from the日." $\mathrm{XC}$ IX.

As the flower draws its coloring from the youth's

fair countenance, so does the poet find in him the virtue and beauty which inspires his verse.

"I grant, sweet love, thy lovely argument Deserves the travali of a worthier pen, Yet what of thee thy poet doth invent He robs thee of and pays it theo again. He lends thee virtue, and he stole that word From thy behaviour; beauty doth he give And found it in thy cheok."

LXXIX.

"The mystical confusion with and in the Frlend of all

that 1s beautiful or lovable in the Poet and others

is a development from the Platonic theory of the

Idea of Beauty: the eternal type of which all beautiful things on earth are but shadows." ${ }^{1}$ In sonnet LII even the beautiful faces of centuries gone by are but poor counterparts of him the poet worships.

"What 18 your substance whereof are you made, That millions of strange shadows on you tend? Since every one hath, every one, one shade, And you, but one, can every shadon lend. Describe Adon1s, and the counterfeit

1

Wyndham. p. 358 . 
Is poorly imitated after jou;

On Helen s cheok all art of beauty set, And you in Grecian tires are painted new; Speak of the spring and folson of the year, The one doth shadon of your beauty shor, The other as your bounty doth appear, And you in every blessed shape we know."

The beautiful persons of ages past have been the unilting prophets of his friend's era.

"Then in the chronicle of wasted time I see descriptions of the falrest wights, And beauty making beautiful old whme In pralse of ladies dead and lovely knights, Then in the blazon of sweet beauty $\mathrm{s}$ best, of hand, of foot, of 11p, of eye, of brow, I see their ant ique pen rould have express'd Even such a beauty as you master now. So all their praises are but prophecies of this our time, all you prefiguring."

CVI.

Shakespeare, with a protesting gesture, seeks to stay the advance of Time, which would destroy beauty's sole prototype.

"O(Time) carve not with thy hours my love's fair brow, Nor dran no lines there $\mathbf{i t h}$ thine antique pen; Him in thy course untainted do allow For beauty's pattern to succeeding men." $\mathrm{XIX}$.

He decries false art which strives for beauty by artificial means, presenting in bold contrast, the friend whose beauty bears no taint of unreality.

"In him those holy antique hours are seen, Without all ornament, itself and true, raking no summer of another's green, Robbing no old to aress his beauty new, And him as for a map doth Nature store, To show false art what beauty was of yore." LXVIII.

Sonnet LXVII expresses the 1dea that in no other human belng does Nature display such perfect artistry. 
"Why should poor beauty indirectly seek Roses of shadow, since his rose is true? For she (Nature) hath no exchequer now but his, And, proud of many, lives upon his gains. 0 , him she stores, to show what wealth she had In days long since, before these last so bad."

Although there are others whom the poet has once loved and whose deaths he has at one time mourned, he sees them all now living in the likeness of his friend.

"Thy bosom is endeared with all hearts, Which I by lacking have supposed dead Thoir Images I loved I vien in thee, And thou, all they, hast all the all of me." XXXI.

H19 concelts have carried him far from the orlginal Platonic concept of an abstract and eternal beauty, for when he centers all beauty w1thin one boy, that quality becomes temporal and must cease to exist at his friend's death. Such a conviction is expressed in Sonnet XIV.

"Thy end is truth's and beauty's doom and date." And again in Sonnet CIV.

"-..- Hear th1s, thou age unbred, Ere you were born was beauty's summer dead." The poet extends this concelt beyond the realm of beauty when his frlend assumes the dimenglons of the world.

"You are so strongly in my purpose bred That all the world besides methinks are dead." CXII.

Nay more, the univerge! 
"For nothing this wide universe I call, Save thou, my rose, in it thou art my all." CIX.

Some evidence that the poet all but accepts the Platonic theory of reminiscence appears in Sonnet LIX.

"O, that record could with backward look, Even of flve hundred courses of the sun, Show me jour image in some antlque book, Since mind at first in character was done!"

Here is expressed a bellel in the preexistence of his 1

friend. According to the theory set forth in the Platonic account, the capacity of a mortal to recognize true beauty rests upon hls abllity to recell that divine beauty, which he has once beheld in a former spiritual existence.

The Platonic lover is one who desires more than mere physlcal beauty in the object of his devotion. He seeks for the intanglble qualities of virtue, truth wisdom; and "when, along with this beauty of person, there is found the additional charm of a susceptible, generous, intelligent ind -.- the bodily sympathy (becomes) spiritualized and absorbed by the mental." Then the lover has taken one step upward on that Platonic ladder, which, if courageously elimbed, will lead him into a realm of glorifled abstractions. Shakespeare does not reach the ladder's top as does

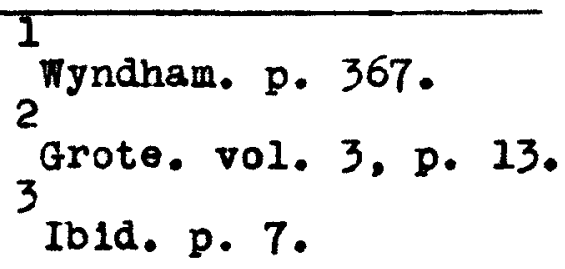


Spenser, but he is not content to remain upon the lowest round of sensual desire, nor yet upon that higher round of the aesthetic appreciation of a beauty which the eye alone detects. This obvious beauty according to the Platonic theory, was necessary to awaken in him sublime memorles, which would, in turn fire him with intense desires. Once material beauty has performed 1ts task, has startled the apathetic lover out of his prolonged sleep, it should gite way to the more subtle inroads of an invisible beauty that the most discerning oye cannot detect. Shakespeare mounts a higher round of Platonic mysticlsm when he percelves the eye's inadequacy.

"Yet eyes this cunning want to grace their art; They draw but what they $8 \theta \theta$, know not the heart." XXIV.

In Sonnet XLVI Shakespeare writes of the opposing demands made upon him by his eye and heart, and he bestows on each 1ta special privilege.

"Mine eye and heart are at a mortal war How to divide the conquest of thy sight, Mine eje my heart thy pictures sight nould bar, uy heart mine eye the freedom of that right. ky heart doth plead that thou in him must 11e, A closet never plerced with cryatal eyes-But the defendant doth that plea deny And says in him thy fair appearance lies. To 'clde this titio is impanneled A quest of thoughts, all tenants to the heart, The clear eye's molety and the dear heart's part: As thus, mine eye's due is thy outward part, And my heart's right thy inward love of heart."

The Platonic significance of this sonnet is that it 
show the trend of the poet' mind anay from the mere sensuous delight in outward perfection toward a desire for some ungeen reallty. Te mark here a growth in the nature of $\mathrm{h} 1 \mathrm{~s}$ desire, which $1 \mathrm{~s}$ becoming more Platonic in scope, "the desire of good things and of belng happy." Beauty of form alone does not sat isfy $h 1 m$, but it must be accompanied by truth.

"O, hor much more doth beauty beauteous seem By that sweet ornament which truth doth give!" LIV. "Shakespeare, when he handles the Truth of Beauty, does so almost always with but a secondary allusion or with no allusion at all, to his Friend's constancy." We find some inconsistency here between the poet's lines and his erlend's behavior. Desiring to find truth where beauty dwells, in accordance with the Platonic concept, yet meeting with disiliusionment because of his friend's conduct, the poet dellberately practices a self-deception, that truth and beauty may be reconciled.

"So shall I 1ive, supposing thou art true, Like a decelved husband, so love's faca lay still seem love to me, though alter'd new; Thy looks with me, thy heart in other place: For there can Iive no hatred in thine eye, Therefore in that I cannot know thy chanje. In many's looks the false heart's history

\footnotetext{
1

Plato. vol. 5, p. 187 . 2 Wynaham. p. 364 .
} 
WILLIAM SHAKESPEARE

Is writ in moods and frowns and wrinkles strange, But heaven in thy creation did decree That in thy face sweet love should ever dwell; Whate'er thy thoughts or thy heart' s workings be, Thy looks should nothing thence but sweetness tell. How like Eve's apple doth they beauty grow, If thy sweet virtue answer not thy show."

XCIII.

He again assoclates the 1deas of truth and beauty

in sonnet $C I$.

"Both truth and beauty on my love depends, so dost thou (uuse) too, and therein dignified."

In Sonnet CXVII we feel the polgnancy of his desire for more than an outmard beauty.

"-.. I did but strive to prove The constanog and virtue of your love."

As the Greek philosopher desires in the youth of his cholce not only a conely person but also a quick intelligence, so Shakespeare seoks through his friend some mental refreshment.

"So are you to my thoughts as food to 1110. or as sweet sesson'd showers are to the ground." LXXV.

And again in Sonnet LXXXII he writes

"Thou art ag fair in knowledge as in hue."

Sonnet IXIX opens with a tribute to outward beauty, which the world does rightful homage to in the poet's friend.

"Those parts of thee that the world's eye doth view Want nothing that the thought of hearts can mend; All tongues, the voloe of souls, give thee that due, Uttering bare truth, even so as foes commend. Thy outward thus with inward praise is crown'd."

But it closes with a loyal attempt by the poet to 
discred1t slanderous comments upon the young man's behavior, which does not bespeak a mind in harmony with his fair countenance. The very fact that Shakespeare refuses to belleve his friend's reputed falseness polnts toward that Platonic attitude which would always associate the beautiful with the good and would point to material loveliness as an index to the soul's perfection.

"They look into the beauty of thy mind, And that in guess, they messure by thy deeds. Then, churls, their thoughts, although their eyes were kind To thy fair Ilower add the rank smell of meeds." LXIX.

When Shakespeare emphasizes the Importance of the mind, 1ts freodom from any physical restriction, he again is in the realm of Platonio thought.

"If the dull substance of my flesh were thought Injurlous distance should not atop my way, For then, despite of space, I would be brought, From limits far remote where thou dost stay For nimble thought can Jump both sea and land As soon as think the place where he would be." XIIX.

A similar conceit occurs in sonnet XXVII.

"-..- my thoughts, from far where I ablde, Intend a zealous pligrimage to thee."

Again in Sonnet XLVII.

"-.-- elther by thy picture or my love, Thyself away art present still with me; And thou not farther than my thoughts canst move, And I ain st1ll with them and they with thee." 
A poet1cal "madness" selzes upon the poet in Sonnet CXIII, when all that he beholds takes on the likeness of his friend. The firm conviction of the mind belles the testimony of the eye, and renders it untrue.

"Since I left you, mine eye is in my mind; For if it see the rudest or gentlest sight,
The most sweet favour or deformed'st creature,
The mountain or the sea, the day or night,
The orow or dove, 1t shapes them to jour feature.
Incapable of more, replete mith you,
My most true mind thus makes mine eye untrue." The supreme desire in the heart of the Platonic lover 18 to become 1mmortal; and Platonic love may be defined as "the 1mpulse towards self-perpetuation which agltates both bodies and minds throughout nature." To quote from the symposium: "the mortal mind ever seeks, as best it can, to be 1mmortal." 2 According to the doctrine set forth in the symposium, the soul is immortal only in so far as the body has the power to beget new 11fe; thus the soul of the old body continues to live in the new. When a man longs for an helr, his basic desire is that that perconslity or being which is himself be preserved in another human belng and not be utterly cast away at death. A son is a partial satisfaction to a man's yearning after eternal life. Potentially then, all men may be considered Platonic lovers since they are lovers of lmmortallty. Materlallsm, however, has ob-
'Grote. vol. 3, p. 6
2 Plato. vol. 5, p. 195. 
structed their progress. Thej have taken the in1tial step in love's fulfillment and rested content, missing the joyous consummation of the soul's glad pligrimage up to divine Idea. Such an experience is not to be achleved miraculously but through the slow processes of growth and development. Shakespeare takes but the first step in his opening sonnets. He is urging his friend to wed, in order that the beauty of his face and form may be preserved in the succeeding generation.

"Thou art thy mother's glass, and she in theo Calls back the lovely April of her prime: So thou through windows of thine age shalt $B \theta \theta$ Desplte of wrinkles this thy golden time." II I.

The emphasis in these early sonnets is placed on the perpetuation of outward forms of beauty.

"From falrest creatures we desire increase That thereby beaut ${ }^{\prime}$ s rose might never die, But as the riper should by time decrease, His tender heir might bear his memory."

And again

"Be, as thy presence 18, graclous and kind, or to thyself at least kind-hearted prove. Make thee another self, for love of me, That beauty st11l may ilve in thine or thee."

Sonnet XI in ruthless words expresses the thought that beaut1ful bodies, because of thelr knherent worth, shall be renewed, whereas unlovely forms should per18h. 
"Herein 110s wisdom, beauty and increase.

Let those whom Nature hath not made for store,

Harsh featureless and rude, barrenly perish."

According to the Symposium, "an individual man or

animal cannot be immortal: he can only attain a

quasi-1mmortality by generating a now individual to 1

replace himself." Pursuing this theory, Shakespeare

urges upon his friend the necessity of marrying.

" ... nothing 'gainst Time's scythe can make defence Save breed, to brave him when he takes thee hence." XII.

And again

"Then how, when nature calls thee to be gone What acceptable audit canst thou leave, Thy unused beauty must be tomb'd with thee, Which, used, Iives th' executor to be."

What is true in human $11 f e$ and animal iffe has its parallel in plant 11fe.

"Then, were not summer's distillation left, A liquid prisoner pent in walls of glass, Beauty's effect with beauty were bereft, Nor it nor no remembrence what it was:

But flowers distill'd, though they with winter meet, Leese but their show; their substance still lives sweet." V.

A popular concelt of the sixteenth century poet is that limmortality may be enjoyed through the medium of verse. Thus Shakespeare lifts his friend out of death's oblivion.

"But thy eternal summer shall not fade

Grote. vol. 3, p. 6. 
Nor lose possession of that falr thou owest; Nor shall Death brag thou wander'st in his shade, When in eternal lines to time thou growest." XVIII.

This thought is frequently found recurring throughout the series. Such a concept points to the Platonic theory that the mind has the capacity to beget Ideas which will 11ve after it.

The first series of one hundred and twenty-six sonnets, which shakespeare addresses to his friend, 1 ends with an attack on Time. It seems a logical venture in the theme of lmmortality, and it marks the apex of Shakespeare's Platonic theorizing. "Since Ideal Beauty is true, is very Truth, it is independent of T1me, and eternal; it, with the love It engenders, is also independent of accident and is unconditioned." ${ }^{2}$ Shakespeare in his use of the word "Love" is departing from the Platonic "Eros" which "like phllosophy, represents a continual aspiration and advance toward a goal never attained." The poet does not preserve that nice distinction which Grote points out should be maintained between love or desire, and the object desired. In sonnets CVII and CXVI the term "love" 1s synonymous,

$2_{\text {Tyndham p. } 367 .}^{\text {Ibid. }}$
$3_{\text {Grote. vol. 3, p. } 10 .}$


not with "desire", but with "the 'Ideas' of Plato (whlch) are those universal definitions, those universal conceptions." ${ }^{1}$ Although we see little or no evidence that Shakespeare has grown to love abstract truth and beauty with the passion of Plato for whom "abstract ldeas themselves became animated, living persons, almost corporeal, as if with hands and eyes", nevertheless his great soul rises to proclaim the triumphant gospel of a love, which 1s 1mmortal, and "makes antiquity for aje his page." (CVII.)

" Love is not love Which alters when it alteration finds, or bends with the remover to remove. 0 , no: it is an ever-f1xed mark That looks on tempests and is never shaken; It is the star to every wandering bark, Whose worth's unknown, although his height be taken. Love's not Time's fool, though rosy lips and cheoks Within his bending sickle's compass come; Love alters not with his brief hours and weoks, But bears it out even to the edge of doom." CXVI.
1.
Pater. p. 146. 2
Ib1d. p. 152 . 


\section{CHAPTER V}

OTHER PLATONIC ELIZABETHANS 


\author{
CHAPTER V \\ OTHER PLATONIC ELIZABETHANS
}

Philip sidney, while far from being a consistent Platonic lover, in certain poetic moods experiences a loftiness of desire, which for the time $11 \mathrm{ftg} \mathrm{him}$ into the realms of mystio1sm. "In sidney there is a direct reference to the power of Plato's thought to lead the mind from the desire with which he is struggling."

"... mine own writings, like bad servants show uy wits quick in vain thoughts, in virtue lame; ---Plato I read for nought but if he tame Such coltish years .....

Astrophel and stel1a, Sonnet XXI)

Although Sonnet XLVIII praises Stella's virtuous soul, the poet's desire reaches out after nore substantial nourishment than the contemplation of her irreproachable character. Possessing a capacity for recognizing and honoring virtue, sidney evinces no Platonic love for 1t. In fact he concelves of it as a hindrance to his love.

"A strife is grown between Virtue and Love, While each pretends that stella must be his; Her eyes, her Iips, her all, saith Love, do thus, Since they do wear his badge, most firmig prove, But virtue thus that doth disprove That Stella,.- o dear name! that Stella 18 That virtuous soul, sure heir of heav'nly bliss, Not this fair outside, which our heart doth move,

Harrison, J. S. Platonism in Engl1sh Poetry. p. 137. 
And therefore, though her beauty and her grace Be Love's Indeed, In stella's self he may

By no pretenoe claim any manner place. Fell, Love, since this demur our sult doth stay, Let Virtue have that Stella's self; jet thus, That Virtue but that body grant to us."

Stella proves the truth of the platonle concept that Virtue and Beauty are one, for her physlcal charms accord with her noble behavior. Yet in sonnet LXXI the poet still clings to his earthly love. "Love 1s both of the flesh and of the spirit, and such is the love of which sidney sings." ${ }^{1}$

"Who will in fairest book of Nature know How virtue mag best lodg'd in beauty be, Let him but learn of Love to read in thee, Stella, those fair lines which true goodness show. There shall he find all vices' overthrow, Not by rude force, but sweetest soverelgnty of reason, from whose light those night-birds fly, That inward sun in thine ejes shineth so. And, not content to be Perfection's heir Thyself, dost strive all minds that way to move, Tho mark in the what is in thee most fair: So while thy beauty draws the heart to love, As last thy virtue bends that love to good: But, ah, Desire still crles, glve me some food."

The final sonnet of the Astrophel and Stella serles, however, marks a glorlous triumph of Platonic love. It acclaims soul victor over sense and wreaths the poet's brow in the laurels of truth and grandeur. At last he has cast off his garment of flesh and girded his loins with the cloth of spiritual beauty.

"Leave me, O Love, which reachest but to dust, And thou my mind, aspire to higher things; Grow rich in that which never taketh rust;

1

Drinkwater, John. Critical Introduction to S1dney's Poems. p. 56. 
Whatever fades, but fading pleasures brings. Draw in thy beams and humble all thy might To that sweet joke, where last freodoms be; Which breaks the clouds, and opens forth the light That doth both shine and give us sight to see. o take fast hold; let that 11ght be thy gulde In this small course which birth draws out to death, And think hor evil becometh him to slide Who seeketh heav'n and comes of heav'nly breath. Then farewell, world; thy uttermost I see: Eternal Love, maintein thy Lifo in me." (CX.)

This poem is a striking example of Plato's theory that actuated by "obvious beauties", man can ultimateIy achleve "that highest beauty". Had sidney written no other poem, this one sonnet like the eingle stroke of a cathedral bell would have sounded forth the majesty of his Platonic soul. "Divine love continues the earthly love; he was imprisoned in this and frees himself. -.- Spiritual instincts pierce through the dominant paganism and ere they make Christians, make Platonists."

T11llam Drummond of Hawthornden possesses many of the characteristica of a Platonic lover. He accepts the theory of reminiscence, believing that in some pre-existence he has seen the beauty of his loved one, and that his earthly passion is but the burning of celestial fire kindled by his divine idea of her before his form or hers took shape in a material world. "That learned Greclan, who did so excel 1 Taine, H. A. A History of Engligh Literature. book 2, p. 126. 
In know ledge passing sense, that he $1 \mathrm{~s}$ nam'd of all the after-worlds divine, doth tell That at the time when first our souls are fram'd, Ere in this mansions blind they come to dwell, They live bright rays of that eternal light, And others see, know, love, in heaven's great helght, Not tolled with aught to reason doth rebel. Most true 1t 1s, for stralght at the first sight My mind me told, that in some other place It elsewhere saw the 1dea of that face, And lov'd a love of heavenly pure dellght; No wonder now I feel so falr a flame Sith I her lov'd ere on this earth she came." Sonnet VII.

He 1s a writer whose deeply religlous nature has responded to the mysticlsm of Plato. He "had in him the making of a Platonic philosopher; but as sir Thomas Browne would have said, he 'Chrlstianized hls notions'! I In Song II he relates how in a drean a beautiful virgin, the soul's embodiment of his lost love, appears to solace him, and bids him cast off that frenzled grief which threatens to becloud his spiritual vision, She points him to a new and infinite vitality that makes his brief and circumscribed existence upon earth seom death 1tself in contrast, and bles him view a beauty, falrer than her own dim shadow of divine perfection.

"If we seem falr, 0 think how fair is he Of whose fair falrness shadows, steps we be. No shadow can compare 1t w1th the face, No step with that dear foot which did it trace; Your souls 1mmortal are, then place them hence, And do not drown them in the mist of sense: Do not, $O$ do not, by false pleasures' might Deprive them of that true and sole delight.

\footnotetext{
1

Ward, Wm. C. Introductory Memo1r, Poems of William Drummond. p. XIV.
} 
That happiness ye seek is not below; Earth's sweetest joy is but disguised noe."

(11. 231-240)

She is the apostle of heavenly love and heavenly beauty.

"o leave that love which reacheth but to dust, And in that love eternal only trust, And beauty, which, when once 1t 18 possest, can only fill the soul, and make it blest."

She speaks as one whom revelation has inspired; no mortal she, but one whom death has delfied.

"If once thou on that only Fair couldst gaze, What llames of love would he within thee raise! In what a mazing maze would it thee bring. To hear but once that quire celestial sing! The falrest shapes on which thy love did selze, Which erst did breed delight, then would displease Be but dark pictures of that sovereign Fair." (11. 211-225)

He catches something of her vision.

".... how foolish he had been To think nought be, but what he there had seen!" (11. 169-170)

Love is of the spirit. It should not attach itself to corruptible forms but should seak fulfillment in an adoration of the divine being.

"Sith 1t hath pleased that First and only Fair To take that beauty to himself again, Which in this world of sense not to remain, But to amaze, was sent, and home repair; The love which to that beauty I did bear (Yade pure of mortal spots which did it stain, And endless, which even death cannot impair) I place on Him who will it not disdain. No shining eyes, no locks of curling gold, No blushing roses on a virgin face, No outward how, no, nor no inward grace, Shall force hereafter have my thoughts to hold: 
Love here on earth huge storms of care do toss, But plac'd above, exempted is erom 108s."

(Sonnet XIII)

Once freed from human limitations the lover exper-

lences a glorious expansion of vision.

"Above th1s vast and admirable frame, Th1s temple visible, which World we name -

There is a world, a norld of perfect bliss, Pure, 1mmaterial, bright."

(Song II. 11. 111-118)

It is a

"--_-.--.-- happy dwelling-place

Where visibly th Invisible doth relgh!

Blest people, who do seo true beauty s face."

(Urania. p. 140.11.9-11)

In his capacity for a purely spiritual ecstasy, Drummond achieves the crest of Platonic mysticlsm. He

1s a lover who has been led

"With chaste and pure desire

To turn unto the loadstar of all bl1ss,

On God the mind to rest,

Burnt up with sacred Plre,

Possessing him, to be by him possesst."

(An Hymne of True Happiness)

John Donne calls upon Platonism to assist him

in thinking through some of the problems that assail

h1s analgtical mind, especially in regard to the per-

sonality of woman. During the sixteenth century there

are tro Platonic conceptions of woman: first, she is

the source of all virtue; second, her nature 18 the universal soul." These 1deas occur in the poetry of Donne, who attempts to account for the indisputable

fact that woman exerts an Immeasurable influence upon 
the physical, mental, and moral nature of man. He surveys her with meticulous scruting in order to determine just wherein $11 e s$ her undeniable power; and be arrives at the conclusion that virtue, which at one time dwelt with man, exiled by him, has departed to reside with woman. Herein then 18 the secret of her attraction,-- that virtue has assumed her form. So woman in the capacities of virtuous wife and mother, 1s become the physical embodiment of heaven.

"If the world's age and death be argued well By the sun's fall, which now towards earth dath tend, Then we might fear that virtue, since she fell So low as woman should be near her end.

But she's not stooped, but raised; exiled by men She fled to heaven, that's heavenly things, that's you She was in all men thinly scattered then, But now a mass contracted in a few.

She gllded us, but you are gold; and she Informed us, but transubstant lates you. Soft dispositions, which ductile bo, Elixirlike, she makes not clean but new.

Though you a w1fe's and mother's name retain 'Tis not as women, for all are not so;

But virtue, having made you virtue, is fain To adhere in these names, her and you to show.

Else, beling alike pure, we should nelther see; $A s$, water being into alr rarefled, Ne1ther appear, till in one cloud they be, So, for our sakes, you do low names abide." (To the countess of Huntingdon)

It is Donne's impassioned verse to the woman of his heart which presents with greater appeal his Platonic ldealism. As is the manner of such lovers, he 
exalts the personal attributes of his loved one to a degree of perfection found only in heavenly beings. " . I thought thee

(For thou lovest truth) an angel, at first sight." (The Dream)

But Donne with his rare aptitude for achieving startling concelts, places the personality of his love even above the sphere of angels. He attempts to place her higher than very heaven.

"...- when I saw thou savest my heart, And knew'st my thoughts beyond an angel's art

I must confess, it could not choose but be Profane, to think thee anything but thee."

(The Dream)

His belief in her lmmortality would of course follow. When she suffers from a fever and he fears for her Ilfe, out of his ashen terror lest she die leaps the brave flame of a celestial vision of her.

"Thy beauty and all parts which are thee Are an unchangeable firmament."

\section{(A Fever)}

But more than that, she cannot die, for her soul anlmateg the world.

"But yet thou canst not die, I know;
To leave this world behind is death;
But when thou from this world wilt go,
The whole world vapours with thy breath.
Or 1f, when thou, the world's soul go'st
It stay, 'tis but thy carcase then." (A Fever)

There is a strange blending of passion and Platonism In the love of John Donne. He admits that he has 
never asplred to them

"....... which soar no higher

Than virtue or the mind to admire."

(The Explration)

In fact, do we not glimpse a slight gesture of superlority toward those who theorize on love, foregoing actual experience with it?

"Love's not so pure, and abstract as they use To say, which have no mistress but their Muse." (Love's Growth)

Yet certainly this love of Donne's is not content to know only a gratifleation of physical desire, for

"H1s mind hath found Affection's ground

Beyond time, place, and mortality."

(Present in Absence)

H1s happiness does not depend upon the proximity of his loved one, for his heart discounts the human hindrances of space and time.

"Absence, hear thou this protestation Against thy strength, Distance, and length;

Do what thou canst for alteration: For hearts of truest mettle Absence doth join and Time doth settie."

(Present in Absence)

Yet paradoxically enough, when tind has conquered matter, its very triumph gratifies the flesh.

"By absence thls good means I gain That I can catch her, Where none can match her, In some close corner of my brain; There I embrace and k188 her: And so I both enjoy and miss her.

(Present in Absence)

Again he refuses to regard a separation as interfering in any way with the satiafaction of a love which is 
the outgrowth of the mind and soul.

"Dull sublunary lover's love

- Whose soul is sense - cannot admit

of absense, 'cause 1t doth remove

The thing which elemented 1 t.

But we - we-

Inter-assured of the mind,

Care less ejes, lips, and hands to miss.

Our two souls therefore, which are one, Though I must go, endure not yet

A breach, but an expansion, Like gold to airy thinness beat."

-(Valediction Forbidding Mournins

Donne cannot dissoclate hls love from a human personal1ty. He cannot joy, as does Drummond, in a fond abstraction, and wonders

"-...-.- by my troth, what thou and I

Did till we loved

If ever anj beauty I did seo,

Which I desired, and got, "Tras but a dream of thee." (The Good-Morron)

Their meeting brings a spiritual rebirth, a grand adventure which embraces all experience.

"And now good-morrow to our waking souls Which watch not one another out of fear; For love all love of other sights controls, And makes one little room an everywhere. Let sea-dlscoverers to new worlds have gone; Let maps to other, worlds on worlds have shown, Let us possess one world; each hath one, and 1s one." (The Good-Morrow)

He becomes ldentified with hla love.

"My face in thine oye, thine in mine appears, And true plain hearts do in the faces rest; Where can we find two better hemispheres Without sharp north, without declining west?"

(The Good-yorrom)

Singly their souls knew human blemishes; united, they 
have merged into a pure harmony of being, which breeds the germ of immortality.

"Whatever dies, was not mixed equally;

If our two loves be one, or thou and I

Love so allke that none do slacken, none can die." (The Good-Morron)

Such union of the epirit reveals the mystery of sex attraction, which culminates in a refinement of the soul.

This ecstasy doth unperplex (Ne sald), and tell us what we love;

We see by this, it was not sex; We see, we sam not, what did move:

But as all severs souls contain Mixture of things they know not what, Love these $m 1 x^{\prime} d$ souls doth $m i x$ again, And makes both one, each this, and that

When love with one another so Interanimates two souls, That abler soul, which thence doth flow, Defects of loneliness controls.

Te then, who are th1s new soul, know, of what we are composed and made,

For th'atomies of which we grow Are souls whom no change can invade."

(The Ecstacy)

So love for Donne remains (Plato to the contrary)

an ecstasy to be enjoyed by two.

"Only our love hath no decay;

This no tomorrow hath, nor yesterday. But truly keeps his first-last-everlasting day." (The Anniversary)

In the sonnet series, Idess Mrrour. Michael Drayton volces an elevated and often purely spiritual desire, which bespeaks a Platonic lover. In Amour I 
he thus addresses Idea.

"Reede heere (smeet mayd)

uy soules oblation to thy sacred name:

Which name my Muse to highest heaven shal raise

By chast desire, true love, and vertues praise."

Again in Amour 2 he professes a chastity of purpose.

"Look thou into my breast, and thou shalt see

Chaste holy vowes for my soules sacrifice."

The death of passion marks the birth of divine love.

"So in loves death shall loves perfection prove That love divine which I have borne to you Whose pure Idea never tongue exprest."

(Amour 39 )

The Neo-Platonic exaltation of noman appears in

Drayton's sonnet sequence. Through Idea the lover

beholds God himself. She is "My soule-shrinde saint,

my faire Idea" (Amour 13), for she is the

"--

The lively Image of Divinitie."

(Amour 46)

Love for her has revealed to the poet the intricate

workings of the soul.

"That learned Father which so firmly proves

The soule of man immortall and divine,

And doth the severall offices define,

Gives her that name as shee the body moves,

Then is she love imbracing Charitie,

uoving a will in us, it is the wind,

Retayning knowledge, still the same in kind;

As intelectuall it is the memorie,

In judging, Reason onely is her name,

In speedy apprehension it is sence,

In right or wrong, they call her conscience. These of the soule the severall functions bee,

Which my hart lightened by thy love doth see."

( To the soule)

Harrison gives two interpretations of Neo-Pla-

tonic love; it "meant either a love devoid of all 
sensual desire, an innocent or hopeless passion, or It was a form of gallantry used to cloak immorality." The sonnets of Samuel Daniel addressed To Della relate a "hopeless passion", whioh can find sat lsfaction only in contemplation and spiritual fervor. We find expressed in them the Renalsance concept of a love exlsting in the soul alone. Desire with

"-.- spotles love hoovers with white wings About the temple of the proudest frame," (XII) of "her that sits in my thoughts Temple salnted." (XV.) "Oft have I told her that my soule did love her." (XVII.)

He bids her

"Relgne in my thoughts, my love and life are thine." (XXIV.)

His are the pleasures, not of the body but of the mind.

"Raigne in my thoughts falre hand, sweete eye, rare Possesse me whole, my harts triumvirat." (XXV.)

Beauty and goodness are reconclled in Della as they are in Stella.

"A modest maide, deckt with a blush of honour Sacred on earth, design'd a saint above. Chastitie and Beauty, which were deadly foes, Live reconclled friends within her brow." ( VI.)

Her virtue has made her an immortal.

"That grace, that vertue, all that serv'd $t$ ' in Dooth her unto eternitie assommon." ('XXXVII.) 1 Harrison. p. 160. 
Platonic tendencies are not confined to a narrow group but are apt to appear at random throughout the galaxy of versatile Elizabethans who can "ging both high and low". Like bright, uncertain butterflies tempted by the sweet of many flowers, they light irresolute upon this fair conceit and that. The fragile bloom of Plato's mysticism holds for them an ephemeral charm. Too palld to satisfy their more vigorous moods, It often solaces their soul's sad langulshings. They dwell upon their ladies' virtues then, discounting mere feminine beauty unless it be confirmed by moral excellences of divine origin. In such an exalted mood the Elizabethan lover looks for moral beauty in his loved one, wishes to see

"Heaven plctured in her face."

He desires her to be

"More than most fair, full of that heavenly fire, Kindled above to show the Maker's glory! Beauty's first-born, in whom all powers conspire 2 To write the Grace's IIfe, and Muses' story."

She is the epitome of all the human virtues.

"Chaste as th' Arabian bird, who all the Ayr denyes And ev'n in Flames experes, when with her self lyes. Oh! she's as kind as drops of new faln April showers, That on each gentle breast, spring fresh perfuming flowers; She's Constant, Gen'rous, Fixt, she's Calm, she is the All

1

de Vere, Edw., Earl of Oxford. What cunning can express 2 Greville, Sir Fulke, Lord Brook. More than most fair. 
Te can of Vertue, Honour, Fa1th, or Glory Call." She so transcends her mortal lover that he can but worshlp her in chaste humility of heart.

"My lady's like no mortal flower That hath 1ts birth upon this earth

She is above my humble love

That but looks up in still delight The stars are high within the sky; I reach them not for they are bright." (of His Lady. Anon.)

We find Elizabethan poets constantly striving to lay hold upon abstractions. Virtue, love, beauty, soul, mind,-- these beckon them bejond the sensual charms of bird song, flower fragrance, sunset coloring, and woman's tender flesh. They look within themselves for deeper truth and find a lurking de1ty.

"I know the heavenly nature of my mind." They hold that

"... the mind, which is divine, runs never to decay." For them a mistress's true worth

".......... shall be seen 4 In form and beauty of her mind."

They scorn base lovers, blind followers of Cupid, who

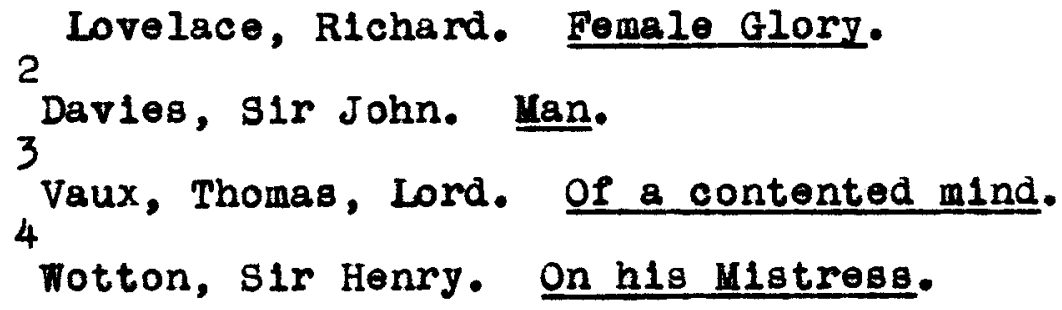


never glimpse the white peaks of pure, unimpassioned m1nd.

"Muses, that sing love's sensual emperie, And lovers kindiling your enraged fires At Cupld's bonfires burning in the eye. Blown with the empty breath of vain desires; You, that prefor the painted cabinet Before the wealthy jevels it doth store ye, That all your joys in dying figures set, And stain the IIving substance of your gloryAbjure those joyg, abhor their memory; And let my love the honoured subject be of love, and honour's complete history. Your eyes were never yet let in to $s e \theta$ The majesty and riches of the mind, But dwell in darkness, for your god is blind."

Only chaste, Platonic love, exalting spirit over matter, virtue over vice, can ultimately approach the exalted state of "pure Intelligence".

"For as you can unto that height refino All Loves delights, as while they do incline Unto no vice, they so become divine, We may as woll attain your excellence, As, whout help of any outward sense ${ }^{2}$
Fould make us grow a pure Intelligence."

Beauty becomes far more than a bewitching face set in a halo of becoming curls.

"Her looks declare her loving mind;
Her count'nance and her heart agree."

Aga in

"May I flind a woman true:

There is beauty's falrest hue! There is beauty, love, and w1t,- 4 Happy he can compass it!"

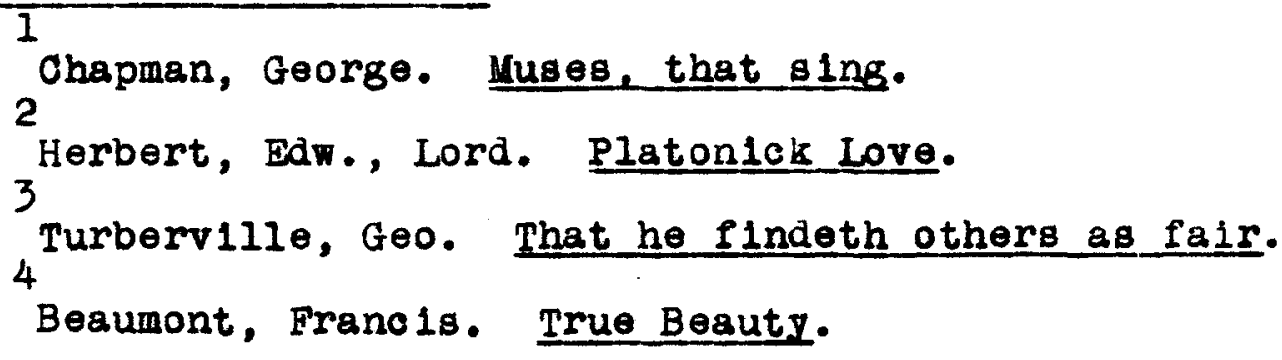


The lover seeks

"Fair beauty mixed with chastity."

He holds that

"-- beauty is no beauty w1thout love,"

for

"Love and beauty 11ve together."

In 1ts highest sense beauty is a divine essence, produc ing an eternal harmony.

"Lovely forms do flow

From concent divinely framed;

Heaven is music, and thy beauty's

Birth is heavenly.

Only beauty purely loving Knows no discord;

But gt 111 moves delight

Like clear eprings renewed by flowing,

Ever perfect, ever in them Selves eternal."

4

Akin to beauty, virtue's self declares "I onely cannot dye", 5 for

"Time canhot vade what virtue made:

Virtue puts back the hand of Time." 6

So one whose 11 fe bespeaks a noble character needs

no uncertain stone to mark her grave. She

1

Anon. Come, Love, lets waik.

2

Campion, Thomas. Thou art not fair.

3

Breton, N1cholas. Pretty, twinkling, starry eyes. 4

Campion, Thomas. Laura.

5

Grimald, Nicholas. Description of Virtue. 6

Anon. Of His Lady. 
"-- In all things with God's virtue filled"

can never pass into oblivion.

"Thus, altho this Yarble must, As all things crumble into dust, And though you find this faire-built Tombe Ashes, as what 1 jeg in it's rombe; Yet her Saint-like name shall shine, A living Glory to this shrine, And her eternal Fame be read, When all, but very Virtue's dead."

The Ellzabethan lover in his Platonic moments is in all respects a soulful one. His yearning is no physical desire but rather a

"-- thirst that from the soul doth rise."

His courtship is placed upon a spiritual plain.

"We saw and mooed each other's eyes;

uy soul contracted then with thine, And both burned in one sacrifice, By which the marriage grew divine." 4

Such love which traffics not with transient flesh

bows to no tyranny of time.

"Time's ever ours while we despise The sensual ldol of our clay." 5

It defles the power of outward circumstance. "

Stone walls do not a prison make, Nor Iron bars a cage;

Minds innocent and quiet take That for an hermitage;

If I have freedom in $\mathrm{my}$ love, And in my ooul am free,

Barnes, Barnaby. The world's bright comforter. 2

Lovelace, Richard. On the Death of urs. F1lmer. 3 Jonson, Ben. To Celie.

Habington, Wm. The Reward of Innocent Love. 5 Ib1d. 


\section{Angels alone, that soar above Enjoy such liberty." 1}

For it the vastness of space presents no handicap.

"Though Seas and Land betw1xt us both Our faith and troth

Like separated souleg

All time and space controules Above the highest sphere wee meet
Unseene, unknowne, and greet as Angels greet."

It has projected itself beyond the living body into

the pure realm of spirit.

"So then we doe anticipate Our after-fate, And are alive in th' okies If thus our I1ps and eyes Can speake like spirits unc onfin'd In Heav'n their earthiy bodies left behind." 3

The Platonic poet would snare love in the meshes of

a definition.

"Love is the blossom where there blow日 Everything that lives or grows:

Love doth make the heavens to move And the sun doth burn in love." 4

Aga in

"-.- true love is a durable fire, In the mind ever burning, Never slck, never old, never dead, From itself never turning."

It never suffers change.

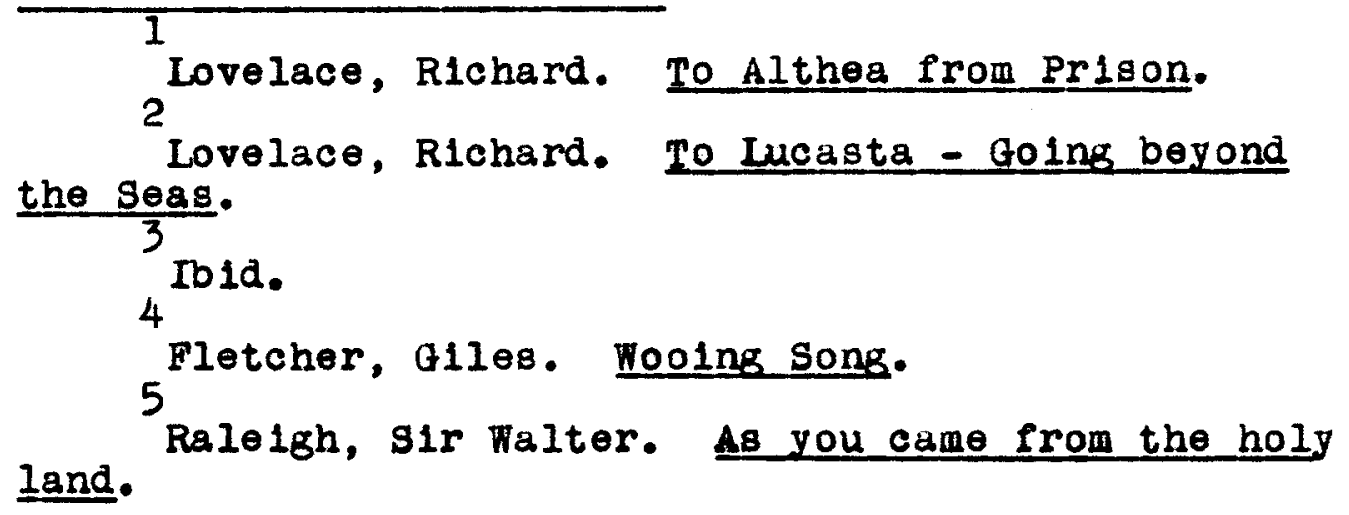


"True love is st11l the same; the torrid zones, And those more frigid ones

It must not know.

For love grown cold or hot

Is lust, or friendghip, not

The thing we have."

Such "love can never die!"

The lover plights an eternal troth.

"Nay, and after death, in sooth,

I to thee w111 keep my truth." 3

He sees in death no hindrance to his love.

"Yea, when the spirit gives up And body breathes his last,

Say naytheless 'my heart is hers'

When Ilfe and all is past." 4

Such constancy is possible because love is immortal.

"Beauty, strength, youth are flowers but fading seen; Duty, falth, love, are roots, and ever green." 5

It is religion's best interpreter.

"O holy Love, religlous saint!

Thou art the treasure, treasure of the soul,

That great celestial powers dost control.

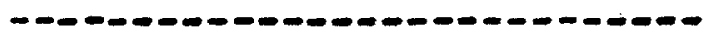

Love is a holy, holy, holy thing." 6

It purifies a lover's purposes.

"And thou, 0 love, which in these eyes

\footnotetext{
1

Suckling, S1r John. True Love. 2

L1ll lat, John. Song. 3

Anon. Love me 11ttle, love me long. 4

Turberville, Goo. To his ring given to his lady. 5 $\frac{\text { turned. }}{6}$

Peele, Geo. His golden locks time hath to silver

Chester, Sir Robert. Ditty.
} 
Hast married reason with affection

And made them salnts of beautie's skyes, Where joys are ghadows of perfection, Lond mo thy ings that I may rise

Up, not by worth, but thy election: For I have vowed in strangest fashion To love, and never seek compassion." 1

It elevates his hopes.

"Love winged my hopes and taught me how to ely Far from base earth $--^{-1} 2$

And since "Love loves truth" it will direct true sons of Plato to

"1 of Nature's riches in her beauties placed," 4 and bid them

" -.. there in conteinplation feed desire,

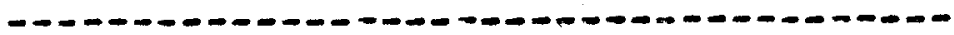

For those sweet glories, whlch you do asplre, Must, as idea's, only be embraced."

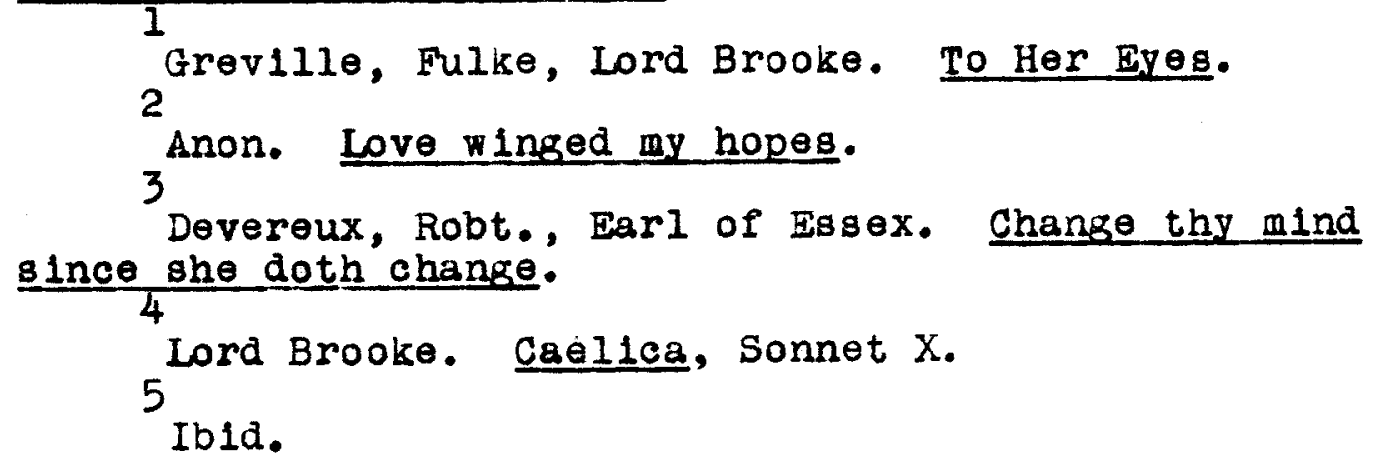


CHAPTER VI.

CONCLUS ION 
CHAPTER VI. CONCLUS ION

Platonic phllosophy had a varled appeal for Ellzabethan poets. It appealed to religlous natures because its doctrines could be easily blended with Christian teachings. Spenser worshipped a Savior whose countenance partook of Plato's beauty; he found within the bosom of his God eternal wisdom; he applied the Calvinistic doctrine of election to the Platonic conviction that only a select group of phllosophers could behold with unclouded vision the Ideas of beauty and virtue and w1sdom. Drummond turned to christ and Plato for comfort in his bereavement, and, reachIng beyond an earthly love, clasped to himself the heavenly love of God. When "obvlous beautles" became for him mere shadows of diviner things, then death was swallowed up in victory.

Platonic philosophy had not only a Christian appeal but also an aesthetic value, for 1ts theory of love began with a desire for tangible beauty. In the "greener times" of his youth Spenser penned vivid lines deplcting the rare loveliness of feminine cheek and Iip; while Shakespeare pald immortal homage to 
the fair person of a peerless youth. All lovers of natural beauty felt the appeal of Plato's ploturesque phllosophy, which saw in a material world the gracloug images of a sublime perfection.

Platonic ethics beckoned to rigid moralists, to lovers of chastity, of sobriety, of truth, and virtue. For Plato held no thing to be beautiful unless it was likewise good. The passionate sidney leaned heavily upon Plato's supporting staff when Stella's charms excited fleshly appetites. Daniel and Drayton in chaste contemplation adored their ladies' virtuous characters. Consclous-stricken Spenser, who found In Plato relief for every mood, was led by him to tune his sensuous string to heavenly airs.

Passionate natures were not chllled upon the atmospheric heights of Platonisin. Had they been, the eager hearts of sixteenth century singers would have looked elsewhere than to Plato for one to guide them to their highest notes. They found in him a lover whose intense flame burned whiter than their own. Desire's flerce polgnancy permeated his whole theory of love, and suffered no abatement when flxed upon ldeas instead of men. Plato remained a lover to the end, embracing spiritual beauty with a far divinor rapture than 1ts enticing earthly counterpart. 
Reasoning minds were intrigued by Plato to attempt minute analyses of love and woman. John Donne examined both beneath metaphysical lenses to deterinine the source and extent of their power, often plecing his findings together with Platonic theorles.

If for no other reason, many embraced Renalssance Platonies as a fad. Wits of the day, to confirm their erudition, must dabble occasionally in Plato. This popularizing of an 1deal led to a miserable subversion of its truth by shallow and 11centlous persons, whose so-called Platonic love meant no more than base passion.

The real apostles of Plato (and there were very few who grasped the full signiflcance of the philosopher's exalted purpose) were the mystics. Their ine souls buojantly soared with his into a realm of intellectual ecstasy. Their desires, sharpened to a keen edge, rent in train the vell of an earth1y temple; and their clear eyes beheld a limitless eternity. Only those with superbly spiritual natures such as Edmund Spenser, ever comprehended in 1ts entirety the grandeur and the profundity of Platonic love. 
B IBLIOGRAPHY 
Ault, Norman. Ellzabethan Lyrics. Nen York, 1925.

Bullen, A. H. Shorter Ellzabethan Poems. Nestminster, 1903.

Castiglione, Count Baldassare. The Book of the Courtier, done into English by S1r Thomas Hoby, Anno 1561. Everyman Edit1on.

Cory, Herbert E. Edmund Spenser, a Critical Study. Berkelej, California, 1917.

Donne, John. Poet 1cal Norks. Boston, 1855.

Drayton, Michael. Minor Poems. Edited by Cyril Brett. Oxford, 1907.

Drummond, Filliam. Poems. Edited by William Ward. 2 vols. New York.

Erskine, John. The Elizabethan Lyric. New York, 1916. Fletcher, J. B. The Religion of Beauty in Foman. New York, 1911.

Garrett, Edmund. Ellzabethan Songs. Boston, 1891. Grote, George. Plato and the Other Companions of

Harrison, J. S. Platonlsm in English Pootry. New York, 1903.

Legouls, Emile and L. Cazamian. A History of English Literature (650-1660). New York, 1926.

Lovelace, Richard. Poems. Edited by C. H. Wilkinson. oxford, 1925.

Padelford, Frederich M. Early Sixteenth Century Lyrics. London and Boston, 1907.

Pater, Walter. Plato and Platonlam. New York, 1908.

Plato. W1th an English Translation by W. R. M. Lamb. 5 vols. London and New York, 1925. 
Reed, Edward B. Engl1sh Lyrical Poetry. New Haven, 1912 .

Renwick, Wm. L. Edmund Spenser. London, 1925.

Shakespeare, Wm. Sonnets. Published by David McKay. PhIladelphia.

Sidney, S1r Ph1lip. Poems. Edited with an introduction by John Drinkwater. New York, 1922.

Spenser, Edmund. Poetical Norks. Edited nith crit1cal notes by J. C. Smith and E. De Selincourt. London, 1926.

Taine, H. A. H1story of Engl1sh Literature. Translated from the French by H. Van Laun. New York, 1880.

Turner, Wm. History of Phllosophy. New York, 1903.

Fyndham, George. Essays in Romant 1c Literature. London, 1919. 